\title{
RNA Interference Strategies for Future Management of Plant Pathogenic Fungi: Prospects and Challenges
}

\author{
Daniel Endale Gebremichael ${ }^{1}$, Zeraye Mehari Haile ${ }^{1,2}{ }^{(0)}$, Francesca Negrini ${ }^{1}$, Silvia Sabbadini $\left.{ }^{3}{ }^{(}\right)$, \\ Luca Capriotti ${ }^{3}$, Bruno Mezzetti ${ }^{3,4}$ (i) and Elena Baraldi ${ }^{1, *}$ \\ 1 Department of Agricultural and Food Sciences (DISTAL), University of Bologna, viale Fanin 44, \\ 40126 Bologna, Italy; danend2000@yahoo.com (D.E.G.); zerayemehari.haile2@unibo.it (Z.M.H.); \\ francesca.negrini6@unibo.it (F.N.) \\ 2 Ethiopian Institute of Agricultural Research (EIAR), P.O. Box 2003, Addis Ababa 1000, Ethiopia \\ 3 Department of Agricultural, Food and Environmental Sciences, Marche Polytechnic University, \\ 60131 Ancona, Italy; s.sabbadini@staff.univpm.it (S.S.); 1.capriotti@pm.univpm.it (L.C.); \\ b.mezzetti@staff.univpm.it (B.M.) \\ 4 Research Group on Food, Nutritional Biochemistry and Health, Universidad Europea del Atlántico, \\ 39011 Santander, Spain \\ * Correspondence: elena.baraldi@unibo.it
}

\section{check for} updates

Citation: Gebremichael, D.E.; Haile, Z.M.; Negrini, F.; Sabbadini, S.; Capriotti, L.; Mezzetti, B.; Baraldi, E. RNA Interference Strategies for Future Management of Plant Pathogenic Fungi: Prospects and Challenges. Plants 2021, 10, 650. https://doi.org/10.3390/ plants10040650

Academic Editor: Alexandra S. Dubrovina

Received: 4 March 2021

Accepted: 25 March 2021

Published: 29 March 2021

Publisher's Note: MDPI stays neutral with regard to jurisdictional claims in published maps and institutional affiliations.

Copyright: (c) 2021 by the authors. Licensee MDPI, Basel, Switzerland. This article is an open access article distributed under the terms and conditions of the Creative Commons Attribution (CC BY) license (https:/ / creativecommons.org/licenses/by/ $4.0 /)$.

\begin{abstract}
Plant pathogenic fungi are the largest group of disease-causing agents on crop plants and represent a persistent and significant threat to agriculture worldwide. Conventional approaches based on the use of pesticides raise social concern for the impact on the environment and human health and alternative control methods are urgently needed. The rapid improvement and extensive implementation of RNA interference (RNAi) technology for various model and non-model organisms has provided the initial framework to adapt this post-transcriptional gene silencing technology for the management of fungal pathogens. Recent studies showed that the exogenous application of double-stranded RNA (dsRNA) molecules on plants targeting fungal growth and virulence-related genes provided disease attenuation of pathogens like Botrytis cinerea, Sclerotinia sclerotiorum and Fusarium graminearum in different hosts. Such results highlight that the exogenous RNAi holds great potential for RNAi-mediated plant pathogenic fungal disease control. Production of dsRNA can be possible by using either in-vitro or in-vivo synthesis. In this review, we describe exogenous RNAi involved in plant pathogenic fungi and discuss dsRNA production, formulation, and RNAi delivery methods. Potential challenges that are faced while developing a RNAi strategy for fungal pathogens, such as off-target and epigenetic effects, with their possible solutions are also discussed.
\end{abstract}

Keywords: RNA interference; dsRNA delivery; small RNA production; dsRNA formulation

\section{Introduction}

Pathogens have decreased the productivity of crops since the advent of agriculture, and farmers have been exploring ways of safeguarding their crops from these organisms. The use of synthetic pesticides is currently an indispensable means of intensive agricultural systems to guarantee food supply worldwide, protecting crops from pathogens, which otherwise would cause more than $30 \%$ yield losses [1,2]. There is a long tradition of using synthetic pesticides which have been developed and applied to control pathogens. However, the evolution of pathogens resistance to pesticides, together with the concern for the environment and human health, has stimulated demand for more selective, environmentally friendly, and cost-effective alternative control methods for pathogens and pests [3]. Scientists have allocated a great deal of intellectual energy into seeking alternative strategies to reduce crop losses, such as the development of tolerant/resistant plants to pathogens and pests and with increased quality products by using conventional breeding and plant biotechnological tools [4]. More recently, gene silencing through RNA interference (RNAi) is offering a new opportunity for precision breeding and for the development 
of new products for protecting plants from pathogens and pests. RNAi is a conserved eukaryotic mechanism triggered by double-stranded RNA (dsRNA) molecules. It is associated with diverse eukaryotic regulatory processes, including protection against viral infection, control of transposon movement, regulation of genome stability, gene expression, and heterochromatin formation $[5,6]$.

RNAi was first reported by Napoli and colleagues [7] to produce violet petunias, the chalcone synthase gene (CHS), encoding for a key enzyme in flavonoid biosynthesis, was overexpressed by introducing a transgene that resulted in an unintended white petunia phenotype. Further analysis revealed declined expression of both the endogenous and exogenously introduced $\mathrm{CHS}$ gene, which led to the conclusion that the transgene co-suppressed the endogenous CHS gene. A similar phenomenon was reported in the filamentous fungus Neurospora crassa [8], where the introduction of the transgene 'albino-1' resulted in the quelling of the endogenous gene. Similarly, in Caenorhabditis elegans, the injection of dsRNAs led to the silencing of unc-22 gene, highly homologous in sequence to the delivered dsRNA molecules [9]. Over the last two decades, the understanding of RNAi has evolved from initial observation of unexpected patterns of expression to a deeper understanding of a multi-faceted network of mechanisms that regulate gene expression in many organisms [10-12]. Consequently, RNAi is getting research attention also as an environmentally friendly alternative to agricultural pest and pathogen control. In fact, because of its sequence-dependent mode of action, RNAi technology has an enormous range of potential as plant protection application, including control against insects [13], mite pests [14,15], plant pathogens [11,16-18], nematodes, and weeds [10,19-21].

The concept is based on the administration of small RNA (dsRNA/siRNA) molecules that induce the silencing of key genes in pathogenic organisms, thereby limiting/stopping their growth. Delivering dsRNAs to a target organism is a crucial aspect that determines the success of the RNAi technology in crop protection. Delivery can be achieved through host-induced gene silencing (HIGS) RNAi approach, corresponding to in-planta expression of siRNA targeting key genes of the pest/pathogen. Besides HIGS, exogenous delivery of dsRNA can be considered as an alternative approach. In this review selected research findings on RNAi approaches through exogenous delivery of small RNA molecules targeting plant pathogenic fungi will be discussed. Small RNA production techniques, potential limitations, and solutions for the application of RNAi for fungal disease control are also discussed.

\section{RNAi for Resistance against Plant Pathogenic Fungi}

In the past, RNAi in plants has been mainly used to improve resistance to diseases by silencing susceptibility genes, those genes that negatively regulate plant defense responses [22]. During the last decade, however, RNAi has been more exploited to provide plants with so-called "pathogen-derived resistance", where resistance is achieved through small interfering RNAs (siRNAs) able to silence genes that are important for infection or the life cycle of the pathogen [23-25]. The silencing process starts with the cleavage of dsRNAs into 21-25-nucleotide-long double-stranded siRNAs in cytoplasm by Dicer or Dicer-like homologs and sRNA-specific RNase III family enzyme. Dicer protein contains an N-terminal helicase domain, a Piwi/Argonaute/Zwille (PAZ) motif, a dsRNA binding domain, and two RNase III motifs at the C-terminus. Dicer-generated siRNAs are then incorporated into a multi-component protein complex, the RNA-induced silencing complex (RISC), which becomes activated on ATP-dependent unwinding of the siRNA duplex [26]. RISC contains an Argonaute protein that has a sRNA-binding domain and an endo-nucleolytic activity for cleavage of target RNAs [26]. Once the siRNA is incorporated into RISC, it will be unzipped into the guide and passenger strands, the latter will be degraded, and the guide strand will bind to the target mRNA sequence and stimulate its endo-nucleolytic cleavage or will inhibit translation [27]. Although greatly diminished, residual mRNA levels can be detected. Therefore, the RNAi-mediated silencing of a particular gene is commonly referred to as a 'knockdown' rather than a 'knockout' [28,29]. Within the fungal kingdom, 
the mechanistic facets of RNAi were studied in N. crassa $[8,30]$. Since then, RNAi machinery has been recognized in a wide range of fungal species. The use of RNAi as a tool for reverse genetics, targeted at modification of fungal gene expression, is continually growing with a large number of fungal species already proved to be responsive [31]. Furthermore, the functionality of absorbed exogenous RNAi molecules offers excellent adaptability and flexibility in securing the required effects on gene expression of fungi, even without the need to genetically modify the targeted pathogen [11,32]. This homology-based gene silencing stimulated by transgenes (co-suppression), antisense, or dsRNAs has been demonstrated in several plant pathogenic fungi/oomycetes, including different mold fungi, such as Botrytis cinerea, Neurospora crassa, and Sclerotinia sclerotiorum [11,18,33,34]; blast, blight, and rust fungi, such as Fusarium asiaticum, Fusarium graminearum, Magnaporthe oryzae, and Puccinia striiformis f. sp. tritici [17,35-38]; mildew, and others, such as Blumeria graminis, Cochliobolus satious, and Venturia inaequalis [39-41]. Over the past few years, a variety of target genes have been used to test whether RNAi is functional in plant-fungal pathogens (Table 1). To date, the number of successful candidate genes studied that led to reduced fungal growth development is limited, and includes effectors, cell wall elongation, chitinase, and hexose transporter genes. Much work remains to be done to identify suitable fungal candidate genes. Fortunately, opportunities exist to establish high-throughput screening pipelines to find strong candidates.

Table 1. Representative potential target genes tested for controlling pathogenic fungi and oomycetes.

\begin{tabular}{|c|c|c|c|}
\hline Species & Target Gene(s) & Host Plant & References \\
\hline \multirow{2}{*}{ Alternaria alternata } & Putative hydrolase (ACTT2), a host-selective ACT-toxin & Tangerine & [42] \\
\hline & Enoyl-reductase (ACTTS2), a host-selective ACT-toxin & Tangerine & [43] \\
\hline A. flavus and A. parasiticus & Transcription factor (aflR) & Corn and wheat & {$[44]$} \\
\hline \multirow{2}{*}{ A. flavus } & aflS, aflR, aflC, pes1, aflep & Peanut & [45] \\
\hline & aflR & Maize & [46] \\
\hline Blumeria graminis f. sp. tritici & $M L O$ & Wheat & [47] \\
\hline Bipolaris oryzae & Polyketide synthase gene (PKS1) & - & [48] \\
\hline \multirow[b]{2}{*}{ Blumeria graminis } & Avira10 & Barley and wheat & [40] \\
\hline & $\begin{array}{l}\text { BEC1011, BEC1054, BEC1038, } \\
\text { BEC1016, BEC1005, BEC1019, } \\
\text { BEC1040, and BEC1018 }\end{array}$ & Barley & [49] \\
\hline \multirow[b]{2}{*}{ Botrytis cinerea } & Superoxide dismutase (BCSOD1) & French bean & {$[50]$} \\
\hline & Dicer-like 1 and Dicer-like 2 & $\begin{array}{c}\text { Arabidopsis, tomato, } \\
\text { strawberry, grapes, lettuce, } \\
\text { onion, and rose }\end{array}$ & [11] \\
\hline Bremia lactucae & $\begin{array}{c}\text { Cellulose synthase 1, Highly abundant message \#34 } \\
\text { (HAM34) }\end{array}$ & lettuce & [24] \\
\hline \multirow{2}{*}{ Cladosporium fulvum } & Hydrophobin gene (HCf-1) & - & {$[51]$} \\
\hline & First exons of six hydrophobin coding genes & - & [52] \\
\hline Cochliobolus sativus & $\begin{array}{c}\text { GFP, a host-selective toxin (ToxA) and a polyketide } \\
\text { synthase (CsPKS1) }\end{array}$ & Wheat & [41] \\
\hline Colletotrichum gloeosporioides & Transcription factor (PAC1) & - & [53] \\
\hline Fusarium culmorum & FcGls1 & Wheat & [54] \\
\hline
\end{tabular}


Table 1. Cont.

\begin{tabular}{|c|c|c|c|}
\hline Species & Target Gene(s) & Host Plant & References \\
\hline \multirow{3}{*}{ Fusarium graminearum } & Transcription factor (Tri6) & Corn and wheat & [44] \\
\hline & $\begin{array}{c}\text { Cytochrome P450 lanosterol C-14 } \alpha \text {-demethylase genes } \\
\text { CYP51A, CYP51B and CYP51C }\end{array}$ & Arabidopsisand barley & [17] \\
\hline & Chs $3 b$ & Wheat & [55] \\
\hline $\begin{array}{l}\text { Fusarium oxysporum f. sp. } \\
\text { cubense (fusarium wilt) }\end{array}$ & Velvet, Fusarium transcription factor 1 & Banana & [56] \\
\hline F. oxysporum f. sp. & FRP1, FOW2, OPR & Arabidopsis & {$[57]$} \\
\hline Fusarium solanif.sp. pisi & $\beta(1,3)$-D-glucan synthase (FsFKS1) & - & [58] \\
\hline Fusarium solani & Chitosanase (CSN1) & Pea & [59] \\
\hline F. verticillioides & GUS ( $\beta$ glucuronidase) & Tobacco & {$[60]$} \\
\hline Glomus species & Monosaccharide transporter 2 & Potato & [61] \\
\hline \multirow{2}{*}{ Magnaporthe oryzae } & MPG1 and PKS-like gene & & [62] \\
\hline & 37 genes involved in calcium signalling & Barley and wheat & [63] \\
\hline Melampsora lini & Effector protein (AvrL567) & Flax & [64] \\
\hline Moniliophthora perniciosa & $\begin{array}{l}\text { GFP, hydrophobin (MpHYD3) and 1-cys peroxiredoxin } \\
\text { (MpPRX1) }\end{array}$ & - & [65] \\
\hline Mucor circinelloides & Carotenogenic gene (carB) & - & {$[66]$} \\
\hline $\begin{array}{l}\text { Mycosphaerella fijiensis, } \\
\text { Fusarium oxysporum }\end{array}$ & $\begin{array}{c}\text { Nuclear condensin, coatomer alpha, } \\
\text { DNA-directed RNA polymerase, actin cortical patch 2/3, } \\
\text { coatomer zeta, CAP } \\
\text { Methyltransferase, GTP ASE binding protein, } \\
\text { proteasome PRE4, Ribosomal RNA, DNA Polymerase } \\
\text { alpha/delta subunit, Adenylase cyclase, Protein kinase C, } \\
\text { FRQ-interacting RNA helicase }\end{array}$ & - & [67] \\
\hline Ophiostoma novo-ulmi & Endopolygalacturonase (Epg1) & - & {$[68]$} \\
\hline Puccinia triticina & $\begin{array}{c}\text { MAPK, cyclophilin (CYC1), } \\
\text { and a calcineurin (CNB) } \\
\text { regulatory subunit gene }\end{array}$ & Wheat & [69] \\
\hline Puccinia striiformis f. sp. tritici & $P_{s C P K 1} P_{s F u z 7}$ & Wheat & {$[36]$} \\
\hline \multirow{4}{*}{ Phytophthora infestans } & G-protein b-subunit encoding gene (Pigpb1) & Potato & {$[70]$} \\
\hline & Cdc 14 coding gene (PiCdc14) & - & {$[71]$} \\
\hline & G-protein a-subunit gene (Pigpa1) & Potato & {$[72]$} \\
\hline & cdc14 & - & [73] \\
\hline \multirow{5}{*}{ Phytophthora infestans } & bZIP transcription factor (Pibzp1) & Tomato & [74] \\
\hline & $\begin{array}{l}\text { Nuclear LIM interactor-interacting factors (NIFC1 } \\
\text { andNIFC2) }\end{array}$ & Tomato & [75] \\
\hline & Inf1 & & [76] \\
\hline & Putative glycosylated protein (Pihmp1) & Potato & [77] \\
\hline & $\begin{array}{l}\text { Putative ATP-dependent DEAD-box RNA-helicase gene } \\
\text { (Pi-RNH1) }\end{array}$ & Potato & [78] \\
\hline
\end{tabular}


Table 1. Cont.

\begin{tabular}{|c|c|c|c|}
\hline Species & Target Gene(s) & Host Plant & References \\
\hline \multirow{7}{*}{ Phytophthora infestans } & $\begin{array}{l}\text { Four members of the CesA encoding for cellulose synthase } \\
\text { genes }\end{array}$ & Potato & [79] \\
\hline & Effector protein (PiAVR3a) & Tobacco and potato & {$[80]$} \\
\hline & SYR1 & Potato & [81] \\
\hline & Cutinase & Potato & [82] \\
\hline & $\begin{array}{c}\text { Dicer-like (Pidcl1), Argonaute (Piago1/2), Histone } \\
\text { deacetylase (Pihda1) }\end{array}$ & Potato & [83] \\
\hline & $\begin{array}{l}\text { G protein } \beta \text {-subunit (GPB1), Cellulose synthase A2, } \\
\text { Pectinesterase, Glyceraldehyde 3-phosphate }\end{array}$ & Potato & [16] \\
\hline & DCL1, HMP1-, PGB1-, and DCTN1+SAC1 & Potato & [84] \\
\hline \multirow[t]{2}{*}{ P. parasitica var.nicotianae } & $\begin{array}{c}\text { A coding gene considered to be involved in } \\
\text { cellulose-binding }(C B) \text {, elicitor }(E) \text { of defence in plants } \\
\text { and lectin }(L) \text {-like activities }(C B E L)\end{array}$ & Tobacco & [85] \\
\hline & GST & Tobacco & [86] \\
\hline $\begin{array}{c}\text { Phytophthora } \\
\text { nicotianae,Peronospora tabacina }\end{array}$ & Cutinase & Tobacco & [82] \\
\hline \multirow{7}{*}{ Phytophthora sojae } & Heterotrimeric G-protein a subunit (PsGPA1) & Soybean & [87] \\
\hline & $\mathrm{C} 2 \mathrm{H} 2$ zinc finger transcription factor ( $\left.P_{S} C Z F 1\right)$ & Soybean & [88] \\
\hline & MAP kinase encoding gene & Soybean & [89] \\
\hline & $\left(P_{s} S A K 1\right)$ & Soybean & [90] \\
\hline & $\begin{array}{c}\text { Putative seven-transmembrane G-protein-coupled } \\
\text { receptor (GPR11) }\end{array}$ & Soybean & [91] \\
\hline & $\begin{array}{c}\text { PsYKT6, a conserved member gene of the soluble } \\
\text { N-ethylmaleimide-sensitive factor attachment protein } \\
\text { receptors (SNAREs) }\end{array}$ & Tobacco and soybean & [92] \\
\hline & $\begin{array}{c}\text { Crinkling- and necrosis-inducing proteins (CRN) } \\
(P S C R N 63 \text { and PSCRN115) }\end{array}$ & Glycine max & [93] \\
\hline Puccinia striiformis f. sp.tritici & $P_{s C P K 1} P_{s} F u z 7$ & Wheat & {$[36]$} \\
\hline Puccinia striiformis f. sp.tritici & PsCNA1 and PsCNB1 & Barley and wheat & [11] \\
\hline Puccinia triticina & $\begin{array}{c}\text { MAP kinase (PtMAPK1), cyclophilin (PtCYC1), } \\
\text { calcineurin B (PtCNB) }\end{array}$ & Wheat & [69] \\
\hline \multirow{2}{*}{ Sclerotinia sclerotiorum } & $\begin{array}{l}B \text { regulatory subunit (rgb1) of } 2 A \\
\text { phosphoprotein phosphatase (PP2A) }\end{array}$ & Tomato & [93] \\
\hline & Chitin synthase & Tobacco & {$[94]$} \\
\hline Ustilago hordei & GUS and mating-type gene $(b W)$ & & [95] \\
\hline \multirow{2}{*}{ Verticillium dahliae } & $\begin{array}{l}\text { Ave1, SIX gene expression } 1 \text { (Sge1) and necrosis and } \\
\text { ethylene-inducing-like protein (NLP1) }\end{array}$ & Tomato and Arabidopsis & [96] \\
\hline & V. dahliae hygrophobins1 & Cotton & [97] \\
\hline Verticillium longisporum & Chorismate synthase (Vlaro2) & Arabidopsis and rapeseed & [98] \\
\hline Venturia inaequalis & Trihydroxynaphthalene reductase (THN) & Apple & [39] \\
\hline
\end{tabular}

\section{Small RNA Production Technologies}

At present, exogenous application of dsRNA seems a new promising strategy to deploy RNAi for pathogen control in agriculture. To carry out exogenous approaches, silencing experiments have been successfully performed using sequence-specific small RNA molecules produced by different methods (Table 2). Production of dsRNAs can be 
possible by employing either in-vitro $[11,17,99,100]$ or in-vivo synthesis $[101,102]$. Studies have shown that the application of in-vitro synthesized dsRNAs targeting essential fungal genes onto the plant leaf surface attenuated fungal infection by inhibiting fungal growth, altering fungal morphology, and reducing pathogenicity, leading to the development of weaker plant disease symptoms $[11,17,33,37]$. In-vitro methods consist of either enzymatic transcription or chemical synthesis with advantages and disadvantages for both. The enzymatic transcription approach is cost-effective for producing both short and long dsRNA molecules. This method is a source of pure dsRNA based on the annealing of two single-stranded (sense and antisense) RNAs (ssRNAs). Based on the principle of in-vitro transcription, on linearized DNA templates, or PCR-generated templates, the use of commercially available kits to produce dsRNA is widely used. Using in-vitro methods for dsRNA production, fungal resistance has been achieved in a plethora of cases as listed in Table 3. However, these kits are expensive when the production of large amounts of dsRNA is needed [17,103]. For RNAi studies on large-scale application, the enzymatic transcription method is therefore not a practical means of dsRNA production. Chemical synthesis, on the other hand, can produce a large yield of high purity dsRNA, but it is more expensive with the cost of synthesis increasing considerably as the length of the dsRNA increases [104]. Chemical synthesis of siRNA enables control over the quantity and purity of siRNA and it also allows chemical modifications to enhance stability, an important feature needed for delivery. Chemically synthesized siRNAs can be labeled for evaluating siRNA uptake or localization by fluorescence microscopy [105].

Table 2. Advantages and disadvantages of different methods of double-stranded RNAs (dsRNAs)/small interfering RNAs (siRNAs) production.

\begin{tabular}{|c|c|c|c|}
\hline Methods & Advantage & Disadvantages & $\begin{array}{c}\text { Fungal Pathogen } \\
\text { Tested with the } \\
\text { Technology and } \\
\text { References }\end{array}$ \\
\hline \multicolumn{4}{|l|}{ In Vitro } \\
\hline Enzymatic synthesis & $\begin{array}{c}\text { Less expensive } \\
\text { No need to test individual } \\
\text { siRNA separately }\end{array}$ & $\begin{array}{c}\text { Purity and } \\
\text { specificity are } \\
\text { variable }\end{array}$ & {$[11,34,38]$} \\
\hline Chemical synthesis & $\begin{array}{l}\text { Fast/Rapid } \\
\text { High purity }\end{array}$ & Expensive & \\
\hline \multicolumn{4}{|l|}{ In vivo } \\
\hline $\begin{array}{c}\text { Escherichia coli/ } \\
\text { Pseudomonas syringae }\end{array}$ & $\begin{array}{l}\text { Produce large quantities of } \\
\text { dsRNAs at low cost }\end{array}$ & Labor intensive & {$[18]$} \\
\hline Yarrowia lipolytica & $\begin{array}{l}\text { Produce large quantities of } \\
\text { dsRNAs at low cost }\end{array}$ & Labor intensive & \\
\hline
\end{tabular}

Table 3. Summary of exogenously applied RNA molecules to plant pathogenic fungi/ascomycetes.

\begin{tabular}{|c|c|c|c|c|c|}
\hline Host Plant & Species & Target Gene(s) & $\begin{array}{l}\text { Role(s) of Target(s) } \\
\text { Gene(s) }\end{array}$ & $\begin{array}{l}\text { Method of } \\
\text { Production }\end{array}$ & References \\
\hline \multicolumn{6}{|l|}{ Cereals } \\
\hline Barley & Fusarium graminearum & $\begin{array}{c}\text { CYP51A, CYP51B, and } \\
\text { CYP51C }\end{array}$ & Ergosterol biosynthesis & $\begin{array}{l}\text { In vitro (MEGA } \\
\text { script }{ }^{\circledR R N A i ~ K i t ~}\end{array}$ & [17] \\
\hline Barley & Fusarium asiaticum & $\beta 2$ tubulin & Fungal growth & $\begin{array}{c}\text { In vitro (MEGA } \\
\text { script }{ }^{\circledR R N A i} \text { Kit) }\end{array}$ & [37] \\
\hline Barley & Fusarium graminearum & ARGONAUTE and DICER & $\begin{array}{l}\text { Fungal vegetative and } \\
\text { generative growth, } \\
\text { mycotoxin production, } \\
\text { antiviral response }\end{array}$ & $\begin{array}{c}\text { In vitro (MEGA } \\
\text { script@RNAi Kit) }\end{array}$ & [38] \\
\hline Rice & Rhizoctonia solani & $\begin{array}{c}\text { DCTN1, SAC1, } \\
\text { polygalacturonase (PG) }\end{array}$ & $\begin{array}{l}\text { Vesicle trafficking } \\
\text { pathway genes and } \\
\text { virulence factor }\end{array}$ & $\begin{array}{c}\text { In vitro (MEGA } \\
\text { script }{ }^{\circledR} R N A i \text { Kit) }\end{array}$ & [84] \\
\hline
\end{tabular}


Table 3. Cont.

\begin{tabular}{|c|c|c|c|c|c|}
\hline Host Plant & Species & Target Gene(s) & $\begin{array}{l}\text { Role(s) of Target(s) } \\
\text { Gene(s) }\end{array}$ & $\begin{array}{l}\text { Method of } \\
\text { Production }\end{array}$ & References \\
\hline Wheat & Fusarium asiaticum & Myosin 5 gene & $\begin{array}{l}\text { Cytokinesis and actin } \\
\text { filaments organization }\end{array}$ & $\begin{array}{c}\text { In vitro (MEGA } \\
\text { script@RNAi Kit) }\end{array}$ & [106] \\
\hline Wheat & Fusarium asiaticum & $\beta 2$ tubulin & Fungal growth & $\begin{array}{c}\text { In vitro (MEGA } \\
\text { script }{ }^{\circledR} \text { RAi Kit) }\end{array}$ & [37] \\
\hline Wheat & Fusarium graminearum & $\begin{array}{c}\text { RdRP1, AGO1, QDE3, QIP, } \\
\text { AGO2, } \\
\text { DCL1, RdRP2, RdRP3, } \\
\text { RdRP4, and DCL2 }\end{array}$ & $\begin{array}{c}\text { Sexual reproduction } \\
\text { AGO } \\
\text { generative development } \\
\text { DCL1 }\end{array}$ & & [107] \\
\hline \multicolumn{6}{|l|}{ Vegetable } \\
\hline Cucumber & Fusarium asiaticum & $\beta 2$ tubulin & Fungal growth & $\begin{array}{c}\text { In vitro (MEGA } \\
\text { script@RNAi Kit) }\end{array}$ & [37] \\
\hline \multirow{4}{*}{ Tomato } & Aspergillus niger & VPS51, DCTN1, SAC1, $p g x B$ & $\begin{array}{l}\text { Vesicle trafficking } \\
\text { pathway genes and } \\
\text { virulence factor }\end{array}$ & 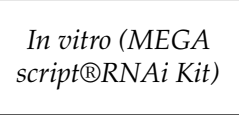 & {$[84]$} \\
\hline & \multirow[b]{2}{*}{ Botrytis cinerea } & $D C L 1$ and $D C L 2$ & Effectors & $\begin{array}{c}\text { In vitro (MEGA } \\
\text { script }{ }^{\circledR R N A i ~ K i t)}\end{array}$ & [11] \\
\hline & & VPS51, DCTN1, SAC1 & $\begin{array}{l}\text { Vesicle trafficking } \\
\text { pathway genes }\end{array}$ & $\begin{array}{c}\text { In vitro }(M E G A \\
\text { script } 囚 R N A i \text { Kit })\end{array}$ & [84] \\
\hline & Colletotrichumgloeosporioides & $\begin{array}{c}\text { DCL 1-2, VPS51, DCTN1, } \\
\text { SAC1 }\end{array}$ & $\begin{array}{c}\text { Effectors and vesicle } \\
\text { trafficking pathway genes }\end{array}$ & 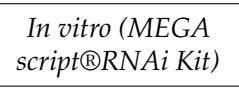 & {$[84]$} \\
\hline \multirow{3}{*}{ Lettuce } & \multirow{2}{*}{ Botrytis cinerea } & DCL1 and DCL2 & Effectors & $\begin{array}{c}\text { In vitro (MEGA } \\
\text { script }{ }^{\circledR R N A i ~ K i t)}\end{array}$ & [11] \\
\hline & & VPS51, DCTN1, SAC1 & $\begin{array}{l}\text { Vesicle trafficking } \\
\text { pathway genes }\end{array}$ & $\begin{array}{c}\text { In vitro (MEGA } \\
\text { script } \circledast R N A i \text { Kit) }\end{array}$ & {$[84]$} \\
\hline & Sclerotinia sclerotiorum & VPS, DCTN1, SAC1 & $\begin{array}{l}\text { Vesicle trafficking } \\
\text { pathway genes }\end{array}$ & $\begin{array}{l}\text { In vitro (MEGA } \\
\text { script }{ } R N A i \text { Kit })\end{array}$ & [84] \\
\hline $\begin{array}{l}\text { Collard } \\
\text { green }\end{array}$ & Sclerotinia sclerotiorum & VPS, DCTN1, SAC1 & $\begin{array}{l}\text { Vesicle trafficking } \\
\text { pathway genes }\end{array}$ & $\begin{array}{c}\text { In vitro (MEGA } \\
\text { script } \circledast R N A i \text { Kit) }\end{array}$ & [84] \\
\hline Onion & Botrytis cinerea & DCL1 and DCL2 & Effectors & $\begin{array}{c}\text { In vitro (MEGA } \\
\text { script@RNAi Kit) }\end{array}$ & {$[11]$} \\
\hline \multicolumn{6}{|l|}{ Oil Crops } \\
\hline Soya & Fusarium asiaticum & $\beta 2$ tubulin & Fungal growth & $\begin{array}{c}\text { In vitro (MEGA } \\
\text { script }{ }^{\circledR R N A i ~ K i t)}\end{array}$ & {$[37]$} \\
\hline Canola & Sclerotinia sclerotiorum & 59 target genes & $\begin{array}{l}\text { Cell wall modification, } \\
\text { mitochondria, ROS } \\
\text { response, protein } \\
\text { modification, } \\
\text { pathogenicity factors, } \\
\text { transcription, splicing, } \\
\text { and translation }\end{array}$ & $\begin{array}{c}\text { In vitro (MEGA } \\
\text { script®RNAi Kit) }\end{array}$ & {$[34]$} \\
\hline \multicolumn{6}{|l|}{ Fruit Crops } \\
\hline \multirow{2}{*}{ Apple } & Aspergillus niger & VPS51, DCTN1, SAC1, pgxB, & $\begin{array}{l}\text { Vesicle trafficking } \\
\text { pathway genes and } \\
\text { virulence factor }\end{array}$ & $\begin{array}{c}\text { In vitro }(M E G A \\
\text { script } \AA R N A i \text { Kit })\end{array}$ & {$[84]$} \\
\hline & Colletotrichum gloeosporioides & $\begin{array}{c}\text { DCL 1-2, VPS51, DCTN1, } \\
\text { SAC1 }\end{array}$ & $\begin{array}{c}\text { Effectors and vesicle } \\
\text { trafficking pathway genes }\end{array}$ & $\begin{array}{l}\text { In vitro (MEGA } \\
\left.\text { script } \AA_{R N A i} \text { Kit }\right)\end{array}$ & [84] \\
\hline
\end{tabular}


Table 3. Cont.

\begin{tabular}{|c|c|c|c|c|c|}
\hline Host Plant & Species & Target Gene(s) & $\begin{array}{l}\text { Role(s) of Target(s) } \\
\text { Gene(s) }\end{array}$ & $\begin{array}{l}\text { Method of } \\
\text { Production }\end{array}$ & References \\
\hline Banana & $\begin{array}{l}\text { Mycosphaerella fijiensis, } \\
\text { Fusarium oxysporum }\end{array}$ & $\begin{array}{c}\text { Nuclear condensing, Coatomer } \\
\text { alpha, DNA-directed RNA } \\
\text { polymerase, ARP 2/3, } \\
\text { Coatomer zeta, Cap } \\
\text { methyltransferase, } \\
\text { GTPase-binding protein, } \\
\text { Proteasome Pre4, Ribosomal } \\
\text { RNA, DNA polymerase alpha } \\
\text { subunit, DNA polymerase delta } \\
\text { Subunit, Adenylase cyclase, } \\
\text { Protein kinase C, } \\
\text { FRQ-interacting RNAhelicase }\end{array}$ & Spore germination & $\begin{array}{c}\text { In vitro (MEGA } \\
\text { script@RNAi Kit) }\end{array}$ & [67] \\
\hline Cherry & Colletotrichumgloeosporioides & $\begin{array}{c}\text { DCL 1-2, VPS51, DCTN1, } \\
\text { SAC1 }\end{array}$ & $\begin{array}{c}\text { Effectors and vesicle } \\
\text { trafficking pathway genes }\end{array}$ & $\begin{array}{l}\text { In vitro (MEGA } \\
\text { script } 囚 R N A i \text { Kit) }\end{array}$ & [84] \\
\hline \multirow{4}{*}{ Grape } & \multirow{3}{*}{ Botrytis cinerea } & $B c C Y P 51, B c c h s 1$, and $B c E F 2$ & $\begin{array}{c}\text { Elongation factor, } \\
\text { ergosterol and chitinase } \\
\text { biosynthesis }\end{array}$ & $\begin{array}{c}\text { In vivo (HT115 (DE3) } \\
\text { E. Coli) }\end{array}$ & [18] \\
\hline & & DCL1 and DCL2 & Effectors & $\begin{array}{c}\text { In vitro (MEGA } \\
\text { script@RNAi Kit) }\end{array}$ & [11] \\
\hline & & VPS51, DCTN1, SAC1 & $\begin{array}{l}\text { Vesicle trafficking } \\
\text { pathway genes }\end{array}$ & $\begin{array}{l}\text { In vitro (MEGA } \\
\text { script } 囚 R N A i \text { Kit) }\end{array}$ & [84] \\
\hline & Aspergillus niger & VPS51, DCTN1, SAC1, pgxB, & $\begin{array}{l}\text { Vesicle trafficking } \\
\text { pathway genes and } \\
\text { virulence factor }\end{array}$ & $\begin{array}{l}\text { In vitro (MEGA } \\
\text { script }{ }^{\circledR} \text { RNAi Kit) }\end{array}$ & [84] \\
\hline Strawberry & Botrytis cinerea & $D C L 1$ and DCL2 & Effectors & $\begin{array}{l}\text { In vitro (MEGA } \\
\text { script }{ }^{\circledR} \text { RAi Kit) }\end{array}$ & [11] \\
\hline \multicolumn{6}{|l|}{ Flowers } \\
\hline \multirow[b]{2}{*}{ Rose } & \multirow[b]{2}{*}{ Botrytis cinerea } & $\begin{array}{l}\text { DCL1 and DCL2 } \\
\text { DCL1 and DCL2 }\end{array}$ & Effectors & $\begin{array}{c}\text { In vitro (MEGA } \\
\text { script }{ }^{\circledR R N A i ~ K i t)}\end{array}$ & [11] \\
\hline & & VPS51, DCTN1, SAC1 & $\begin{array}{l}\text { Vesicle trafficking } \\
\text { pathway genes }\end{array}$ & $\begin{array}{l}\text { In vitro (MEGA } \\
\left.\text { script }{ }^{\circledR} R N A i \text { Kit }\right)\end{array}$ & [84] \\
\hline \multicolumn{6}{|l|}{ Model Plant } \\
\hline Arabidopsis & Botrytis cinerea & DCL1 and DCL2 & Effectors & $\begin{array}{c}\text { In vitro (MEGA } \\
\text { script }{ }^{\circledR R N A i ~ K i t)}\end{array}$ & {$[11]$} \\
\hline Arabidopsis & Sclerotinia sclerotiorum & 59 target genes & $\begin{array}{c}\text { Differentially } \\
\text { upregulated genes }\end{array}$ & $\begin{array}{c}\text { In vitro (MEGA } \\
\text { script }{ }^{\circledR R N A i ~ K i t)}\end{array}$ & [34] \\
\hline Arabidopsis & Fusarium graminearum & CYP51 & Ergosterol biosynthesis & $\begin{array}{c}\text { In vitro (MEGA } \\
\text { script }{ }^{\circledR} \text { RNAi Kit) }\end{array}$ & {$[108]$} \\
\hline Arabidopsis & Verticillium dahliae & DCL 1-2, DCTN1, SAC1 & $\begin{array}{c}\text { Effectors and vesicle } \\
\text { trafficking pathway genes }\end{array}$ & $\begin{array}{l}\text { In vitro (MEGA } \\
\text { script } 囚 R N A i \text { Kit) }\end{array}$ & {$[84]$} \\
\hline Arabidopsis & Macrophomina phaseolina & Chitin synthase (MpCHS) gene & $\begin{array}{l}\text { Catalyze the } \beta-1,4 \\
\text { polymerization of } \\
N \text {-acetylglucosamine }\end{array}$ & & [109] \\
\hline
\end{tabular}

In-vivo production of dsRNA using genetically engineered bacteria (for ex. Escherichia coli and Pseudomonas syringae) and yeast (Yarrowia lipolytica) $[110,111]$ emerged as an alternative approach to produce large quantities of dsRNAs at low cost. Concerning the costs, for example, it is possible to buy a fungus-derived dsRNA sequence produced in bacteria (E. coli) with about $\$ 1$ USD per $1 \mathrm{~g}$ from low-cost companies [112]. These systems are able to produce large amounts of dsRNA molecules needed for field trial applications. Tenllado et al. [113] demonstrated that crude extracts of bacterially expressed dsRNAs are effective in protecting plants from virus infections when sprayed onto plant surfaces by a simple procedure. The use of recombinant bacteria to produce dsRNA is an efficient technique due to their ease of handling, ability to maintain plasmid, and the fast growth rate of bacteria [114]. Among the available E. coli strains, HT115 (DE3) is widely used to produce large 
amounts of dsRNA for exogenous application studies. The E. coli HT115 (DE3) harbors the pro-phage $\lambda \mathrm{DE} 3$ encoding the Isopropyl $\beta$-D-1-thiogalactopyranoside (IPTG) inducible T7 polymerase gene for dsRNA transcription $[101,113,115,116]$. Even though, the bacterial production systems may contain bacterial homologous DNA molecules; that may affect the RNA quality and applicability, crude extracts of dsRNA can be applied on plants to test its efficiency against plant pathogens and pests $[18,117]$. Researchers demonstrated that bacterially expressed dsRNAs can be used to induce RNAi in fungus [18], virus [49], worms [118], and in insect pests [56,119]. Researchers are also using in-vivo dsRNA amplification employing P. syringae harboring the bacteriophage phi6 RNA-dependent RNA polymerase complex [120-122]. Niehl and colleagues [122] demonstrated that the in-vivo dsRNA production by P. syringae has great potential to allow therapeutic dsRNAs to be designed and produced for large-scale crop protection against different fungal and viral pathogens, and insect pests. However, the use of E. coli is still controversial because even if used as lysate containing the dsRNA, its residuals may have an impact on animal and human health [123]. Therefore, alternatives for expressing dsRNA in organisms are being explored, especially those that are generally considered safe for human consumption, which do not produce endotoxins or pose risks to health or the environment. One organism that possesses this characteristic is yeast ( $Y$. lipolytica), which can provide unique advantages for the production of dsRNA. Alvarez-Sanchez et al. [111] observed that Y. lipolytica is a convenient host for producing and delivering dsRNA-ORF89 that can protect shrimp from white spot syndrome virus attack.

Besides other factors, the role of RNAi-based products for controlling fungal pathogens depends on the cost of production. Taking the cost trend into account, it is expected that small RNA production costs will decrease substantially in the future, with commercial companies investing in dsRNA production capacity. Over the past few years, a declining trend in the dsRNA production cost has been recorded. For example, the cost for producing $1 \mathrm{~g}$ of dsRNA using in-vitro nucleoside triphosphate (NTP) synthesis fell from $\$ 12,500$ USD in 2008 to \$60 USD in 2018 [16,124]. For field-scale pest and pathogen management, metric tons of dsRNA will be required. It is conceivable that such a huge demand cannot be satisfied only by an in-vitro dsRNA transcription system. For this reason, some industrial companies have achieved low-cost (almost \$2 USD per $1 \mathrm{~g}$ of dsRNA) and large-scale production of dsRNA using bacteria [112,125].

\section{Exogenous Delivery of Small RNA for Controlling Fungal Pathogens of Plants}

The exogenous delivery method is certainly the most promising approach for the application of RNAi technology in the field [101,126]. This method avoids any modification of crop genomes and can be exploited against virtually any microbial pathogen that is responsive to RNAi approaches [11,127]. Hence, the exogenous method can be an alternative method to HIGS, more easily accepted by public and biosafety authority, and faster to optimize than the obtainment of a HIGS plant. The first observation, explaining exogenous delivery of dsRNA molecules on plants, inducing RNAi of a plant gene, was reported in Nicotiana benthamiana plants pre-treated with the surfactant Silwet L-77 [128]. In this study, in-vitro-transcribed 685 bp dsRNAs and/or chemically synthesized 21-nt sRNAs targeting the endogenous phytoene desaturase mRNA was sprayed on plant surfaces resulting in extensive phytoene desaturase downregulation [128]. In an exogenous RNAi mechanism, to induce RNAi and achieve successful protection against pathogens, two prerequisites are fundamental: i) the sensitivity of the target organism to the silencing process stimulated by dsRNA, and ii) the capability to uptake external RNA molecules from the environment by fungal pathogens $[11,17,127]$, viruses $[122,129,130]$, and insects $[124,131,132]$. Plants and fungi are capable of taking up externally applied dsRNAs and siRNAs. Reports showed that fungi can uptake 21nt sRNA duplexes as well as long dsRNAs of at least up to $800 \mathrm{nt}[11,17]$. The presence of Dicer, Argonaute, and RdRP proteins in several fungal species suggests that they should be capable to display active RNAi mechanisms [31,107,133]. However, exogenous delivery of small RNA to fungi can 
be tricky and for some fungal species has not been achieved yet. The reason underneath reluctance of RNA uptake by some fungal species can be difficult to explore and can be associated with different biological aspects, including the cell wall or membrane biochemical components [11]. For example, Zymoseptoria tritici encodes the core components of the RNAi machinery but still is dsRNA insensitive [23]. The authors have demonstrated through live-cell imaging that the conidiospores of $Z$. tritici were unable to absorb dsRNAs, suggesting that there may not be an encoded dsRNA receptor or a defect in the uptake pathway. Wang and co-workers reported rapid dsRNA uptake from the environment by Botrytis cinerea and that these RNAs were able to suppress fungal genes in a sequence-specific manner [11]. In Sclerotinia sclerotiorum, a scientific study demonstrated that the uptake of dsRNA occurs through clathrin-mediated endocytosis [134]. One of the few recent studies reported that various beneficial or pathogenic fungal and oomycetes organisms have diverse capacity to adsorb fluorescein-labeled dsRNA from the environment, and this competence seems to have an influence on the efficacy of the RNAi when virulence-related gene were targeted through a spray-induced gene silencing (SIGS) approach for the defense of the hosts. The authors showed that Colletotrichum gloeosporioides cannot uptake dsRNA, whereas in Trichoderma virens and Phytophthora infestans RNA uptake was limited. The situation is different in Botrytis cinerea, Sclerotinia sclerotiorum, Rhizoctonia solani, Aspergillus niger, and Verticillium dahliae in which fluorescent dsRNAs are already inside the fungal cells within $6 \mathrm{~h}$ after administration of specific long dsRNA [84]. Overall, information on dsRNA uptake in fungi is scarce, which is due to the limited number of studies conducted on the efficacy of exogenous RNAi against phytopathogenic fungi so far.

\subsection{Formulation of Small RNA}

The overall success of using exogenous RNAi is dependent on the mode of delivery of RNA molecules, application methods, length and/or concentration of dsRNAs, plant-organ specific activities, and stability under unsuitable environmental conditions $[126,129,135,136]$. The main constraint of exogenous applications of naked-dsRNAs is their short-term stability. Complexation of dsRNA with carrier molecules is a solution widely used to overcome this limitation $[135,137,138]$. Although most studies of dsRNA carriers for plant protection have concentrated on insects [139], the improved stability and penetrability of some formulations may also be applied to phytopathogenic fungi. It is tricky to predict when a fungal outbreak will occur and, thus, the longer the protective antifungal treatment on the surface of the plant will remain intact, the more likely it will be successful when the infection occurs. Furthermore, a variety of necrotrophic pathogens, such as S. sclerotiorum, can become systemic in a matter of days within the plant [140]. This underlines the importance of getting the optimized load of dsRNA into the fungus as quickly as possible, and this can be done by carriers that enhance penetrability. In order to increase stability and uptake efficiency, dsRNA can be incorporated into nanoparticles. Nanoparticles are the most common choice made in order to deliver the unstable naked dsRNA/siRNA to the targeted sites since they protect the dsRNA/siRNA from degradation. Besides, they can be used by adding target-specific ligands to their surface for targeted delivery [141]. Chitosan (poly $\beta-1,4$-Dglucosamine) is one of the most widely used polymers to generate nanoparticles to protect and deliver dsRNA/siRNA to target cells [142]. Chitosan has been the topic of many studies, due to its inexpensive production from marine waste, low toxicity, and a wide variety of molecular weights and modifications available $[143,144]$. It has been shown that chitosan-based formulations boost endonuclease stability and uptake in a variety of species of insects $[145,146]$. Another means to obtain an increased RNAi efficiency is through the use of layered double hydroxide clay nanosheets. Positively charged nanosheet stacks bind the dsRNA negative charges electrostatically and provide enhanced protection against environmental factors and nucleases. Mitter et al. [129] reported that loading RNAi inducing dsRNAs into layered double hydroxide clay nanosheets and applying to plant surface enabled sustained release of the dsRNA for up to 30 days. The formulated dsRNAs (Bioclay) offered protection against virus for up to 
20 days post spraying, compared to naked dsRNA which offered 5 days protection window. Owing to this increased period of bioactivity, this technology also holds the potential to be useful in insect and fungal defense. Interestingly, this formulation also seems to facilitate uptake and systemic dissemination within the sprayed host plant [129]. The use of a class of very small nanoparticles, called carbon dots, for the delivery of siRNA to the Nicotiana benthamiana and tomato plants, has also been reported [147]. In addition, a liposome-based delivery method has been applied in insects, fungi, and nematodes [148-150] with success in altering gene expression and/or mortality. It should be stated here that, although carrier compounds considerably facilitate RNA delivery, they are also quite expensive and/or difficult to synthesize. Different administration strategies have been reported in mammalian cells, such as conjugation of dsRNAs to cholesterol, cationic lipids, and cell-penetrating peptides $[151,152]$. Future studies are required to determine whether they also improve dsRNA uptake and efficiency in fungal pathogens.

\subsection{Delivery Methods}

Different application/delivery strategies have been studied in various agricultural pest species and the main dsRNA application methods tested so far include high-pressure spray, injection into trunks, soil application, petiole absorption, brush-mediated application, infiltration, injection, root soaking, soil/root drench, and postharvest spraying of bunches $[11,17,18,124,126,131,132,135,136,153,154]$. When high-pressure spraying was used for the exogenous application of siRNAs, it was successful in inducing local and systemic silencing of the green fluorescent protein (GFP) transgene in N. benthamiana [126]. Here, high-pressure spraying was more effective compared to wiping, infiltration, and gene gun techniques. Direct exogenous application of dsRNA, by spreading with sterile individual soft brushes without using any additional techniques, was also observed successful in inducing efficient suppression of enhanced green fluorescent protein (eGFP) and neomycin phosphotransferase-II (NPTII) transgenes in Arabidopsis [136]. The authors analyzed the effects of different dsRNA concentrations $(0.1,0.35$, and $1.0 \mu \mathrm{g} / \mu \mathrm{l})$ and the concentration at $0.35 \mu \mathrm{g} / \mu \mathrm{l}$ had a higher significant influence on transgene-silencing efficiency [136]. The effects of different lengths of dsRNAs (315, 596, and 977-bp) targeting different virus genes were also investigated in $N$. tabacum leaves, and results indicated that shorter dsRNAs showed reduced antiviral activity, indicating that dsRNA length could influence its efficacy [155]. Overall, fungal uptake of environmental RNAs appears less dependent on RNA size, as both short sRNA duplexes and long dsRNAs are taken up and stimulate strong gene silencing in the fungal cells.

The efficient delivery of dsRNA is crucial in moving RNAi-based fungal control from laboratory to field. dsRNAs not only move within a fungus but they can also transfer from the environment to the fungus (environmental uptake), and between interaction of plants and fungus (cross-kingdom dsRNA trafficking), thereby subsequently inducing gene silencing in the fungal organism [134]. Exogenous RNAs derived from plant fungal pathogens gene sequences can either be directly internalized into fungal cells or indirectly via passage through plant tissue before transport into targeted fungal cells $[11,17,106,156]$. The vascular system of plants translocates RNAs [157]; indeed, RNAi in plants is linked with the production of a mobile signal that can move from cell-to-cell and over long distances. This fact can therefore be useful in the establishment of targeted strategies for the control of pathogens $[158,159]$. With respect to HIGS-in planta stable resistance, exogenous dsRNA applications offer shorter-term protection from fungal infections, but they could be particularly beneficial to shield agricultural food products during post-harvest storage and protecting plant species for which not defined nor efficient transformation protocols are available [127].

Studies conducted on exogenous RNAi concerning fungal pathogens, summarized in Table 3, showed that exogenous application is effective in suppressing fungal growth. For example, a recent study by Werner and colleagues [38] showed that using spray-induced gene silencing (SIGS), targeting Argonaute and Dicer genes of F. graminearum, afforded 
protection of barley leaves from infection by F. graminearum. Similarly, F. asiaticum virulence decreased when in-vitro-transcribed dsRNA targeting its myosin 5 gene was sprayed on wounded wheat coleoptiles [106]. In another study, foliar applications of in-vitro transcribed dsRNAs on canola (Brassica napus), targeting 59 genes of necrotrophic fungi reduced S. sclerotiorum and B. cinerea leaves infection [34]. Spraying of detached barley leaves with dsRNA, 791nt long, targeting three ergosterol biosynthesis genes CYP51A, CYP51B, and CYP51C of F. graminearum, effectively inhibited the fungal growth both in local areas, where the dsRNA was sprayed and in non-sprayed distal leaf parts [17]. These results demonstrate that dsRNA can translocate within the plant. Topical application of dsRNA and sRNAs targeting Dicer-like (DCL) genes of B. cinerea (BcDCL1 and BcDCL2) on the surface of tomato, strawberry, fox grape (Vitis labrusca), iceberg lettuce, onion, rose, and Arabidopsis leaves, effectively suppressed gray mold disease [11]. On the other hand, the capacity of exogenously applied dsRNAs to prevent and counteract infection of $B$. cinerea was tested on grapevine (Vitis vinifera). Three separate approaches for dsRNA delivery into plants were applied, namely, high-pressure spraying of leaves, petiole adsorption of dsRNAs, and postharvest spraying of bunches. The results demonstrated that, independently from the method of application, the exogenous method can decrease the virulence of Botrytis cinerea [18]. These successful experiments of exogenous application indicated that exogenously supplied dsRNA could form the basis for the development of a new tool aimed at protecting crops against fungal diseases.

The exogenous application of dsRNA can be very interesting also on horticultural produces at the postharvest stage [11] and against fungal pathogens, which are capable of producing mycotoxins very harmful to animal and human health $[44,160]$. Their control at the disposition stage is strictly limited to a few active ingredients due to residue concerns. With regard to postharvest pathogens, the halted growth of $B$. cinerea on the surface of fruits, vegetables, and flowers due to dsRNAs and sRNAs of BcDCL1/2 [11] shows the potential of externally applied small RNA as a new generation of sustainable and environmentally friendly products for controlling postharvest pathogens. In addition, it should be recalled that post-harvest products are not exposed to open field environmental conditions such as UV light that promote degradation of dsRNAs and this makes them more suitable for protection during post-harvest.

\section{Challenges of dsRNA-Based Products for Disease Management Strategy in Plants}

Exogenous application of dsRNA molecules has been largely successful to induce RNAi (Table 3), and the studies outlined above highlight several critical aspects that need to be addressed before the development of RNAi-based products against fungal pathogens. Some considerations are required concerning the future application of exogenous RNA molecules against fungi and addressing the major issues that presently limit the viability of RNAi for fungal pathogen control.

\subsection{Epigenetic Effect}

As mentioned above, exogenous RNAi is an efficient transgene-free approach in modern crop protection platforms. In SIGS approaches, RNA molecules are externally applied on plants in order to selectively trigger the degradation of target mRNAs. However, once present in the plant cell, the applied dsRNAs may be processed by DCL4 into 21-nt siRNAs, which slice complementary mRNAs in a process termed post-transcriptional gene silencing [161], and by DCL2 into 22-nt siRNAs, which either recruit RNA-directed RNA polymerase 6 (RDR6) on the complementary mRNA for the generation of secondary siRNAs or repress mRNA's translation $[162,163]$. Finally, DCL3 processes the dsRNA into 24-nt siRNAs, that are involved in RNA-directed DNA methylation (RdDM) of cognate DNA sequences [164]. Thus, in exogenous RNAi methods, the applied dsRNAs can trigger unexpected epigenetic alterations and lead to epigenetically modified plants. DNA methylation refers to the addition of a methyl group to the fifth carbon of the six-ring cytosine residue. DNA methylation was expected to be caused by DNA:DNA interactions 
for a long time, until a groundbreaking study showed that RNA:DNA interactions cause DNA methylation in viroid-infected tobacco plants, which was thus called RdDM [165]. Dubrovina and colleagues [147] applied in-vitro transcribed dsRNA targeting GFP and NPTII genes in transgenic Arabidopsis thaliana carrying a GFP/NPTII cassette. They observed that not only were GFP and NPTII mRNAs downregulated, but also DNA methylation occurred in the corresponding coding region 7 days after administration [136]. Therefore, the information from Dubrovina and colleagues [136] seem to reflect a more general mechanism and support a more careful consideration of possible epigenetic changes in the application of exogenous RNAi, because plants treated with exogenous dsRNAs may still contain no transgenes, but they are still epigenetically modified. In general, the occurrence of epigenetic changes in the genome after the application of exogenous RNAi should be resolved and clarified. This will help better interpret the exogenous RNAi data obtained.

\subsection{Biosafety Considerations}

Because of its sequence-dependent mode of action, there is increasing interest to use RNAi, both in academia and the commercial sector, in the management strategies for a large number of agricultural pests and pathogens as either in planta stable expression or in topical application [166]. RNAi-based plants have been already approved at the commercial level (corn and potato) and others are ready for submission (plum). The main issues for developing the risk assessment on these plants have been already defined [167]. The same biosafety approaches can be used to assess and approve new RNAi-based products for topical application. Below, we try to synthesize the most important aspects that need to be addressed in the risk assessment of plants during exogenous RNAi application. Although the binding of dsRNA/siRNA is believed to be highly specific [168], the siRNAs can bind to off-target genes that have sufficient sequence homology to the target gene [169]. The binding of siRNA somewhere else within the target genome may not be a problem, but concerns increase if off-target binding happens in non-target organisms.

However, to reduce possible effects on non-target species, it is possible to use the sequence-dependent nature of RNAi as an advantage to tailor the design of dsRNA sequences [147]. In fact, at the beginning of the development phase of the exogenous-RNAi mechanism, a thoughtful design of dsRNA will restrict the possibility of non-target effects due to sequence similarity. Designing a unique siRNA/dsRNA, which does not share high DNA identity with other genetic loci greatly limits the probability of off-target effects $[170,171]$. Current siRNA and dsRNA design guidelines for RNAi experiments suggest BLAST similarity searches (http: / / www.ncbi.nlm.nih.gov / BLAST (accessed on 4 March 2021)) [172] against sequence databases to pinpoint potential off-target genes to increase the probability that only the intended gene is targeted [173]. However, the BLAST algorithm was not specifically designed to assess RNAi off-target effects. Therefore, dedicated bioinformatics programs, like the open-access siRNA finder (si-FI) software (https://github.com/snowformatics/siFi21 (accessed on 4 March 2021); Lücketal, 2019), ERNAi (https:/ / www.dkfz.de/signaling/e-rnai3/ (accessed on 4 March 2021)) and dsCheck (http:/ / dscheck.rnai.jp/ (accessed on 4 March 2021)), can also be used to screen the candidate dsRNA/siRNA sequences for complementarity with other genes.

\section{Future Prospects and Concluding Remarks}

Food security is threatened by production constraints including diseases. Crop protection against pathogens relies mostly on the widespread use of chemical pesticides that are applied to the environment in large amounts yearly. Some of these chemicals have been in use for almost half a century. Therefore, there is a need for novel tools that are more sustainable and less detrimental to the environment. RNAi is a novel and promising method that is gaining pace as a technique to cope with pathogens in many economically important crop plants. Despite few limitations, the applicability of RNAi to improve crop resistance, especially against pathogens, is expected to be the most reliable and significant approach in the future, as shown by a plethora of studies. Generally, RNAi has emerged as one of the 
most promising potential control mechanisms for plant pathogens and insects. Although still a lot remains to be explored and understood about the molecular process of RNAi in plants and their pathogens, the current knowledge available and the studies reviewed in this paper have proved that exogenous RNAi technology is an essential tool for identifying gene functions and targeting critical genes to control plant pathogenic fungal development. In-planta stable expression offers a possible long-term stable resistance to diseases. Inplanta stable expression offers the benefits of a long-term stable resistance to diseases, but it is clearly classified as a GMO and needs to follow rules applied for this type of modified plants [167]. Topical application, on the other hand, offers a more flexible solution for developing new dsRNA-based products to be used to protect crops in agricultural systems. Although information on external RNA uptake in fungi is limited, interesting progress has been achieved in B. cinerea, F. asiaticum, F. graminearum, F. Oxysporum, M. phaseolina, M. fijiensis, and S. Sclerotiorum. RNAi technology using the topical application of RNA molecules has emerged as a potential tool for improving various agronomically important plants. RNA-based biocontrol compounds are already under development and there is the perspective that new RNAi based formulates soon will reach the market, with a good cost-benefit balance for their application in different agriculture sectors. This objective now seems quite achievable considering the availability of first documents, the most important one from OECD (http:/ / www.oecd.org/officialdocuments / publicdisplaydocumentpdf/ ?cote $=\mathrm{env} / \mathrm{jm} / \mathrm{mono}(2020) 26 \&$ doclanguage $=\mathrm{en}($ accessed on 4 March 2021)), which indicate risk assessment and regulatory approaches for these new RNAi-based products in line with those applied for the authorization of new biological pesticides [112].

To develop dsRNA-based products, besides the identification of effective dsRNA sequences, we need to develop appropriate formulates and delivering systems depending on the type of fungi and plants. Technological advancement in the field of biotechnology has offered new understandings to detect distinctive target genes. In fungi, the formulation, uptake, and processing of dsRNAs remains relatively undescribed. Analyzing the stability and delivery methods of dsRNAs, and more specifically the uptake of these dsRNAs into the target organism, remains ready for investigation. The delivery of dsRNA via nanoparticle complexes has novel potential for crop protection against pests, especially those refractories to RNAi. The topical use of dsRNA/nanoparticle complexes is expected to be the future of RNAi-mediated control of pests/pathogens without genetic modification of crops. Although carrier compounds considerably facilitate RNA delivery, they are also quite expensive and/or difficult to synthesize. Biosafety approaches already adopted to approve RNAi-based plants can be used for developing the risk assessment for new dsRNAbased products. Existing legislation should be implemented to consider the approval of new dsRNA-based products. Taking into account these aspects, we can think of a very important role in the development of this technology to improve the systems of protection of plants from diseases in a more compatible way with the environment, as foreseen by the new lines expected from the green deal indicated by Europe and of interest in the world [166].

Author Contributions: Conceptualization, all authors; methodology, n.a.; software, n.a.; validation, n.a., n.a. and n.a.; formal analysis, n.a.; investigation, n.a.; resources, n.a.; data curation, n.a.; writing—original draft preparation, D.E.G.; writing—review and editing, all authors; visualization, n.a.; supervision, Z.M.H.; project administration, all authors; funding acquisition, B.M. All authors have read and agreed to the published version of the manuscript.

Funding: This research was funded by EU-PRIMA project MED-BERRY; and MIUR-PRIN2017 national program via Grant No. 20173LBZM2 and The APC was funded by iPLANTA COST ACTION grant number 15223.

Institutional Review Board Statement: Not applicable.

Informed Consent Statement: Not applicable.

Data Availability Statement: The data presented in this study are available in the article. 
Acknowledgments: This publication is based upon work from COST Action iPLANTA (CA15223), supported by COST (European Cooperation in Science and Technology). ZMH and FN are paid on MIUR-PRIN2017 national program via grant N.20173LBZM2-Micromolecule and PRIMA-Partnership for Research and Innovation in the Mediterranean Area 2019-2022 MEDBERRYproject.

Conflicts of Interest: The authors declare no conflict of interest.

\section{References}

1. Alexander, P.; Brown, C.; Arneth, A.; Finnigan, J.; Moran, D.; Rounsevell, M.D. Losses, inefficiencies and waste in the global food system. Agric. Syst. 2017, 153, 190-200. [CrossRef]

2. Keulemans, W.; Bylemans, D.; De Coninck, B. Farming without Plant Protection; EPRS European Parliamentary Research Service: Brussels, Belgium, 2019; ISBN 978-92-846-3993-9.

3. Nicolopoulou-Stamati, P.; Maipas, S.; Kotampasi, C.; Stamatis, P.; Hens, L. Chemical pesticides and human health: The urgent need for a new concept in agriculture. Front. Public Health 2016, 4, 148. [CrossRef]

4. Sabbadini, S.; Capocasa, F.; Battino, M.; Mazzoni, L.; Mezzetti, B. Improved nutritional quality in fruit tree species through traditional and biotechnological approaches. Trends Food Sci. Technol. 2021. [CrossRef]

5. Ketting, R.F. The many faces of RNAi. Dev. Cell 2011, 20, 148-161. [CrossRef] [PubMed]

6. Castel, S.E.; Martienssen, R.A. RNA interference in the nucleus: Roles for small RNAs in transcription, epigenetics and beyond. Nat. Rev. Genet. 2013, 14, 100-112. [CrossRef]

7. Napoli, C.; Lemieux, C.; Jorgensen, R. Introduction of a chimeric chalcone synthase gene into petunia results in reversible co-suppression of homologous genes in trans. Plant Cell 1990, 2, 279-289. [CrossRef]

8. Romano, N.; Macino, G. Quelling: Transient inactivation of gene expression in Neurospora crassa by transformation with homologous sequences. Mol. Microbiol. 1992, 6, 3343-3353. [CrossRef]

9. Fire, A.; Xu, S.; Montgomery, M.K.; Kostas, S.A.; Driver, S.E.; Mello, C.C. Potent and specific genetic interference by doublestranded RNA in Caenorhabditis elegans. Nature 1998, 391, 806-811. [CrossRef] [PubMed]

10. Koch, A.; Kogel, K.-H. New wind in the sails: Improving the agronomic value of crop plants through RNAi-mediated gene silencing. Plant Biotechnol. J. 2014, 12, 821-831. [CrossRef] [PubMed]

11. Wang, M.; Weiberg, A.; Lin, F.M.; Thomma, B.P.H.J.; Huang, H.D.; Jin, H.L. Bidirectional cross-kingdom RNAi and fungal uptake of external RNAs confer plant protection. Nat. Plants 2016, 2, 16151. [CrossRef]

12. Brilli, M.; Asquini, E.; Moser, M.; Bianchedi, P.L.; Perazzolli, M.; Si-Ammour, A. A multi-omics study of the grapevine-downy mildew (Plasmopara viticola) pathosystem unveils a complex protein coding- and noncoding-based arms race during infection. Sci. Rep. 2018, 8, 757. [CrossRef]

13. Zotti, M.; Dos Santos, E.A.; Cagliari, D.; Christiaens, O.; Taning, C.N.T.; Smagghe, G. RNAi technology in crop protection against arthropod pests, pathogens and nematodes. Pest Manag. Sci. 2018, 74, 1239-1250. [CrossRef] [PubMed]

14. Niu, J.; Shen, G.; Christiaens, O.; Smagghe, G.; He, L.; Wang, J. Beyond insects: Current status, achievements and future perspectives of RNAi in mite pests. Pest Manag. Sci. 2018, 74, 2680-2687. [CrossRef]

15. Bensoussan, N.; Dixit, S.; Tabara, M.; Letwin, D.; Milojevic, M.; Antonacci, M.; Jin, P.; Arai, Y.; Bruinsma, K.; Suzuki, T.; et al. Environmental RNA interference in two-spotted spider mite, Tetranychus urticae, reveals dsRNA processing requirements for efficient RNAi response. Sci. Rep. 2020, 10, 19126. [CrossRef]

16. Jahan, S.N.; Åsman, A.K.M.; Corcoran, P.; Fogelqvist, J.; Vetukuri, R.R.; Dixelius, C. Plant-mediated gene silencing restricts growth of the potato late blight pathogen Phytophthora infestans. J. Exp. Bot. 2015, 66, 2785-2794. [CrossRef] [PubMed]

17. Koch, A.; Biedenkopf, D.; Furch, A.; Weber, L.; Rossbach, O.; Abdellatef, E.; Linicus, L.; Johannsmeier, J.; Jelonek, L.; Goesmann, A.; et al. An RNAi-Based control of Fusarium graminearum infections through spraying of long dsRNAs involves a plant passage and is controlled by the fungal silencing machinery. PLoS Pathog. 2016, 12, e1005901. [CrossRef]

18. Nerva, L.; Sandrini, M.; Gambino, G.; Chitarra, W. Double-stranded RNAs (dsRNAs) as a sustainable tool against gray mold (Botrytis cinerea) in grapevine: Effectiveness of different application methods in an open-air environment. Biomolecules 2020, 10, 200. [CrossRef]

19. Hollomon, D.W. Do we have the tools to manage resistance in the future? Pest. Manag. Sci. 2012, 68, 149-154. [CrossRef]

20. Shaner, D.L.; Beckie, H.J. The future for weed control and technology. Pest. Manag. Sci. 2014, 70, 1329-1339. [CrossRef]

21. Iqbal, S.; Fosu-Nyarko, J.; Jones, M.G.K. Attempt to silence genes of the RNAi pathways of the root-knot nematode, Meloidogyne incognita results in diverse responses including increase and no change in expression of some genes. Front. Plant Sci. 2020, 11, 328. [CrossRef]

22. Brodersen, P.; Voinnet, O. The diversity of RNA silencing pathways in plants. Trends Genet. 2006, 22, 268-280. [CrossRef]

23. Kettles, G.J.; Hofinger, B.J.; Hu, P.; Bayon, C.; Rudd, J.J.; Balmer, D.; Courbot, M.; Hammond-Kosack, K.E.; Scalliet, G.; Kanyuka, K. sRNA profiling combined with gene function analysis reveals a lack of evidence for cross-kingdom RNAi in the wheatZymoseptoria tritici pathosystem. Front. Plant Sci. 2019, 10, 892. [CrossRef]

24. Govindarajulu, M.; Epstein, L.; Wroblewski, T.; Michelmore, R.W. Host-induced gene silencing inhibits the biotrophic pathogen causing downy mildew of lettuce. Plant Biotechnol. J. 2015, 13, 875-883. [CrossRef] 
25. Su, X.; Lu, G.; Li, X.; Rehman, L.; Liu, W.; Sun, G.; Guo, H.; Wang, G.; Cheng, H. Host-induced gene silencing of an adenylate kinase gene involved in fungal energy metabolism improves plant resistance to Verticillium dahliae. Biomolecules 2020, 10, 127. [CrossRef]

26. Vaucheret, H.; Vazquez, F.; Crété, P.; Bartel, D.P. The action of ARGONAUTE1 in the miRNA pathway and its regulation by the miRNA pathway are crucial for plant development. Genes Dev. 2004, 18, 1187-1197. [CrossRef]

27. Limera, C.; Sabbadini, S.; Sweet, J.B.; Mezzetti, B. New biotechnological tools for the genetic improvement of major woody fruit species. Front. Plant Sci. 2017, 8, 1418. [CrossRef]

28. Preall, J.B.; Sontheimer, E.J. RNAi: RISC gets loaded. Cell 2005, 123, 543-545. [CrossRef]

29. Wilson, R.C.; Doudna, J.A. Molecular mechanisms of RNA interference. Annu. Rev. Biophys. 2013, 42, 217-239. [CrossRef]

30. Catalanotto, C.; Azzalin, G.; Macino, G.; Cogoni, C. Gene silencing in worms and fungi. Nature 2000, 404, 245. [CrossRef] [PubMed]

31. Dang, Y.; Yang, Q.; Xue, Z.; Liu, Y. RNA interference in fungi: Pathways, functions, and applications. Eukaryot. Cell 2011, 10, 1148-1155. [CrossRef] [PubMed]

32. Nakayashiki, H.; Nguyen, Q.B. RNA interference: Roles in fungal biology. Curr. Opin. Microbiol. 2008, 11, 494-502. [CrossRef]

33. Goldoni, M.; Azzalin, G.; Macino, G.; Cogoni, C. Efficient gene silencing by expression of double stranded RNA in Neurospora crassa. Fungal Genet. Biol. 2004, 41, 1016-1024. [CrossRef]

34. McLoughlin, A.G.; Wytinck, N.; Walker, P.L.; Girard, I.J.; Rashid, K.Y.; De Kievit, T.; Fernando, W.G.D.; Whyard, S.; Belmonte, M.F. Identification and application of exogenous dsRNA confers plant protection against Sclerotinia sclerotiorum and Botrytis cinerea. Sci. Rep. 2018, 8, 7320. [CrossRef]

35. Nakayashiki, H. RNA silencing in fungi: Mechanisms and applications. FEBS Lett. 2005, 579, 5950-5957. [CrossRef]

36. Zhu, X.; Qi, T.; Yang, Q.; He, F.; Tan, C.; Ma, W.; Voegele, R.T.; Kang, Z.; Guo, J. Host-induced gene silencing of the MAPKK gene PsFUZ7 confers stable resistance to wheat stripe rust. Plant Physiol. 2017, 175, 1853-1863. [CrossRef]

37. Gu, K.X.; Song, X.S.; Xiao, X.M.; Duan, X.X.; Wang, J.X.; Duan, Y.B.; Hou, Y.-P.; Zhou, M.-G. A $\beta_{2}$-tubulin dsRNA derived from Fusarium asiaticum confers plant resistance to multiple phytopathogens and reduces fungicide resistance. Pest. Biochem. Physiol. 2019, 153, 36-46. [CrossRef] [PubMed]

38. Werner, B.T.; Gaffar, F.Y.; Schuemann, J.; Biedenkopf, D.; Koch, A.M. RNA-spray-mediated silencing of Fusarium graminearum AGO and DCL genes improve Barley disease resistance. Front. Plant Sci. 2020, 11, 476. [CrossRef]

39. Fitzgerald, A.; Van Kha, J.A.; Plummer, K.M. Simultaneous silencing of multiple genes in the Apple Scab fungus Venturia inaequalis by expression of RNA with chimeric inverted repeats. Fungal Genet. Biol. 2004, 41, 963-971. [CrossRef]

40. Nowara, D.; Gay, A.; Lacomme, C.; Shaw, J.; Ridout, C.; Douchkov, D.; Hensel, G.; Kumlehn, J.; Schweizer, P. HIGS: Host-induced gene silencing in the obligate biotrophic fungal pathogen Blumeria graminis. Plant Cell 2010, 22, 3130-3141. [CrossRef]

41. Leng, Y.; Wu, C.; Liu, Z.; Friesen, T.L.; Rasmussen, J.B.; Zhong, S. RNA-mediated gene silencing in the cereal fungal pathogen Cochliobolus sativus. Mol. Plant Pathol. 2010, 12, 289-298. [CrossRef]

42. Miyamoto, Y.; Masunaka, A.; Tsuge, T.; Yamamoto, M.; Ohtani, K.; Fukumoto, T.; Gomi, K.; Peever, T.L.; Akimitsu, K. Functional analysis of a multicopy host-selective ACT-toxin biosynthesis gene in the tangerine pathotype of Alternaria alternata using RNA silencing. Mol. Plant Microbe Interact. 2008, 21, 1591-1599. [CrossRef]

43. Ajiro, N.; Miyamoto, Y.; Masunaka, A.; Tsuge, T.; Yamamoto, M.; Ohtani, K.; Fukumoto, T.; Gomi, K.; Peever, T.L.; Izumi, Y. Role of the host-selective ACT-toxin synthesis gene ACTTS2 encoding an enoyl-reductase in pathogenicity of the tangerine pathotype of Alternaria alternata. Phytopathology 2010, 100, 120-126. [CrossRef] [PubMed]

44. McDonald, T.; Brown, D.; Keller, N.P.; Hammond, T.M. RNA silencing of mycotoxin production in Aspergillus and Fusarium species. Mol. Plant Microbe Interact. 2005, 18, 539-545. [CrossRef] [PubMed]

45. Arias, R.S.; Dang, P.M.; Sobolev, V.S. RNAi-mediated control of aflatoxins in peanut: Method to analyze mycotoxin production and transgene expression in the peanut/Aspergillus pathosystem. J. Vis. Exp. 2015, e53398. [CrossRef] [PubMed]

46. Masanga, J.O.; Matheka, J.M.; Omer, R.A.; Ommeh, S.C.; Monda, E.O.; Alakonya, A.E. Downregulation of transcription factor aflR in Aspergillus flavus confers reduction to aflatoxin accumulation in transgenic maize with alteration of host plant architecture Plant Cell Rep. 2015, 34, 1379-1387. [CrossRef]

47. Riechen, J. Establishment of broad-spectrum resistance against Blumeria graminis f.sp tritici in Triticum aestivum by RNAi-mediated knock-down of MLO. J. Verbr. Lebensm. 2007, 2, 120. [CrossRef]

48. Moriwaki, A.; Ueno, M.; Arase, S.; Kihara, J. RNA-mediated gene silencing in the phytopathogenic fungus Bipolaris oryzae. FEMS Microbiol. Lett. 2007, 269, 85-89. [CrossRef]

49. Pliego, C.; Nowara, D.; Bonciani, G.; Gheorghe, D.M.; Xu, R.; Surana, P.; Whigham, E.; Nettleton, D.; Bogdanove, A.J.; Wise, R.P.; et al. Host-induced gene silencing in barley powdery mildew reveals a class of ribonuclease-like effectors. Mol. Plant. Microbe Interact. 2013, 26, 633-642. [CrossRef]

50. Patel, R.M.; Van Kan, J.A.L.; Bailey, A.M.; Foster, G.D. RNA-mediated gene silencing of superoxide dismutase (bcsod1) in Botrytis cinerea. Phytopathology 2008, 98, 1334-1339. [CrossRef]

51. Hamada, W.; Spanu, P.D. Co-suppression of the hydrophobin gene HCf-1 iscorrelated with antisense RNA biosynthesis in Cladosporium fulvum. Mol. Gen. Genet. 1998, 259, 630-638. [CrossRef]

52. Lacroix, H.; Spanu, P.D. Silencing of six hydrophobins in Cladosporium fulvum: Complexities of simultaneously targeting multiple genes. Appl. Environ. Microbiol. 2008, 75, 542-546. [CrossRef] 
53. Shafran, H.; Miyara, I.; Eshed, R.; Prusky, D.; Sherman, A. Development of new tools for studying gene function in fungi based on the Gateway system. Fungal Genet. Biol. 2008, 45, 1147-1154. [CrossRef] [PubMed]

54. Chen, W.; Kastner, C.; Nowara, D.; Oliveira-Garcia, E.; Rutten, T.; Zhao, Y.; Deising, H.B.; Kumlehn, J.; Schweizer, P. Host-induced silencing of Fusarium culmorum genes protects wheat from infection. J. Exp. Bot. 2016, 67, 4979-4991. [CrossRef] [PubMed]

55. Cheng, W.; Song, X.-S.; Xiao-Li, Q.; Cao, L.-H.; Sun, K.; Qiu, X.-L.; Xu, Y.-B.; Yang, P.; Huang, T.; Zhang, J.-B.; et al. Host-induced gene silencing of an essential chitin synthase gene confers durable resistance to Fusarium head blight and seedling blight in wheat. Plant Biotechnol. J. 2015, 13, 1335-1345. [CrossRef]

56. Ghag, S.B.; Shekhawat, U.K.S.; Ganapathi, T.R. Host-induced post-transcriptional hairpin RNA-mediated gene silencing of vital fungal genes confers efficient resistance against Fusarium wilt in banana. Plant Biotechnol. J. 2014, 12, 541-553. [CrossRef]

57. Hu, Z.; Parekh, U.; Maruta, N.; Trusov, Y.; Botella, J.R. Down-regulation of Fusarium oxysporum endogenous genes by hostdelivered RNA interference enhances disease resistance. Front. Chem. 2015, 3, 1-10. [CrossRef]

58. Ha, Y.; Covert, S.F.; Momany, M. FsFKS1, the 1,3- $\beta$-glucan synthase from the caspofungin-resistant fungus Fusarium solani. Eukaryot. Cell 2006, 5, 1036-1042. [CrossRef]

59. Liu, H.; Zhang, B.; Li, C.; Bao, X. Knock down of chitosanase expression in phytopathogenic fungus Fusarium solani and its effect on pathogenicity. Curr. Genet. 2010, 56, 275-281. [CrossRef]

60. Tinoco, M.L.P.; Dias, B.B.A.; Dall'Astta, R.C.; Pamphile, J.A.; Aragão, F.J.L. In vivo trans-specific gene silencing in fungal cells by in planta expression of a double-stranded RNA. BMC Biol. 2010, 8, 1-11. [CrossRef]

61. Helber, N.; Wippel, K.; Sauer, N.; Schaarschmidt, S.; Hause, B.; Requena, N. A versatile monosaccharide transporter that operates in the arbuscular mycorrhizal Fungus glomus sp. is crucial for the symbiotic relationship with plants. Plant Cell 2011, 23, 3812-3823. [CrossRef]

62. Nakayashiki, H.; Hanada, S.; Quoc, N.B.; Kadotani, N.; Tosa, Y.; Mayama, S. RNA silencing as a tool for exploring gene function in ascomycete fungi. Fungal Genet. Biol. 2005, 42, 275-283. [CrossRef]

63. Nguyen, Q.B.; Kadotani, N.; Kasahara, S.; Tosa, Y.; Mayama, S.; Nakayashiki, H. Systematic functional analysis of calciumsignalling proteins in the genome of the rice-blast fungus, Magnaporthe oryzae, using a high-throughput RNA-silencing system. Mol. Microbiol. 2008, 68, 1348-1365. [CrossRef]

64. Lawrence, G.J.; Dodds, P.N.; Ellis, J.G. TECHNICAL ADVANCE: Transformation of the flax rust fungus, Melampsora lini: Selection via silencing of an avirulence gene. Plant J. 2009, 61, 364-369. [CrossRef]

65. Caribé dos Santos, A.C.; Sena, J.A.L.; Santos, S.C.; Dias, C.V.; Pirovani, C.P.; Pungartnik, C.; Valle, R.R.; Cascardo, J.C.M.; Vincentz, M. dsRNA induced gene silencing in Moniliophthora perniciosa, the causal agent of witches' broom disease of cacao. Fungal Genet. Biol. 2009, 46, 825-836. [CrossRef]

66. Nicolas, F.E.; Torres-Martínez, S.; Ruiz-Vázquez, R.M. Two classes of small antisense RNAs in fungal RNA silencing triggered by non-integrative transgenes. EMBO J. 2003, 22, 3983-3991. [CrossRef]

67. Mumbanza, F.M.; Kiggundu, A.; Tusiime, G.; Tushemereirwe, W.K.; Niblett, C.; Bailey, A. In vitro antifungal activity of synthetic dsRNA molecules against two pathogens of banana, Fusarium oxysporum f. sp. cubense and Mycosphaerella fijiensis. Pest Manag. Sci. 2013, 69, 1155-1162. [CrossRef]

68. Carneiro, J.S.; De La Bastide, P.Y.; Chabot, M.; Lerch, L.; Hintz, W.E. Suppression of polygalacturonase gene expression in the phytopathogenic fungus Ophiostoma novo-ulmi by RNA interference. Fungal Genet. Biol. 2010, 47, 399-405. [CrossRef]

69. Panwar, V.; McCallum, B.; Bakkeren, G. Endogenous silencing of Puccinia triticina pathogenicity genes through in planta-expressed sequences leads to the suppression of rust diseases on wheat. Plant J. 2013, 73, 521-532. [CrossRef]

70. Latijnhouwers, M.; Govers, F. A Phytophthora infestans G-protein beta subunit is involved in sporangium formation. Eukaryot. Cell 2003, 2, 971-977. [CrossRef]

71. Ah Fong, A.; Judelson, H.S. Cell cycle regulator Cdc14 is expressed during sporulation but not hyphal growth in the fungus-like oomycete Phytophthora infestans. Mol. Microbiol. 2003, 50, 487-494. [CrossRef]

72. Latijnhouwers, M.; Ligterink, W.; Vleeshouwers, V.G.A.; VanWest, P.; Govers, F. A G-alpha subunit controls zoospore motility and virulence in the potato late blight pathogen Phytophthora infestans. Mol. Microbiol. 2004, 51, 925-936. [CrossRef]

73. Whisson, S.C.; Avrova, A.O.; Van West, P.; Jones, J.T. A method for double-stranded RNA-mediated transient gene silencing in Phytophthora infestans. Mol. Plant Pathol. 2005, 6, 153-163. [CrossRef]

74. Blanco, F.A.; Judelson, H.S. A bZIP transcription factor from Phytophthora interacts with a protein kinase and is required for zoospore motility and plant infection. Mol. Microbiol. 2005, 56, 638-648. [CrossRef]

75. Judelson, H.S.; Tani, S. Transgene-induced silencing of the zoosporogenesis-specific NIFC gene cluster of Phytophthora infestans involves chromatin alterations. Eukaryot. Cell 2007, 6, 1200-1209. [CrossRef]

76. Ah-Fong, A.M.; Bormann-Chung, C.A.; Judelson, H.S. Optimization of transgene-mediated silencing in Phytophthora infestans and its association with small-interfering RNAs. Fungal Genet. Biol. 2008, 45, 1197-1205. [CrossRef]

77. Avrova, A.O.; Boevink, P.C.; Young, V.; Grenville-Briggs, L.J.; van West, P.; Birch, P.R.J.; Whisson, S.C. A novel Phytophthora infestans haustorium-specific membrane protein is required for infection of potato. Cell. Microbiol. 2008, 10, 2271-2284. [CrossRef]

78. Walker, C.A.; Köppe, M.; Grenville-Briggs, L.J.; Avrova, A.O.; Horner, N.R.; McKinnon, A.D.; Whisson, S.C.; Birch, P.R.; Van West, P. A putative DEAD-box RNA-helicase is required for normal zoospore development in the late blight pathogen Phytophthora infestans. Fungal Genet. Biol. 2008, 45, 954-962. [CrossRef] 
79. Grenville-Briggs, L.J.; Anderson, V.L.; Fugelstad, J.; Avrova, A.O.; Bouzenzana, J.; Williams, A.; Wawra, S.; Whisson, S.C.; Birch, P.R.; Bulone, V.; et al. Cellulose synthesis in Phytophthora infestans is required for normal appressorium formation and successful infection of potato. Plant Cell 2008, 20, 720-738. [CrossRef]

80. Bos, J.I.B.; Armstrong, M.R.; Gilroy, E.M.; Boevink, P.C.; Hein, I.; Taylor, R.M.; Zhendong, T.; Engelhardt, S.; Vetukuri, R.R.; Harrower, B.; et al. Phytophthora infestans effector AVR3a is essential for virulence and manipulates plant immunity by stabilizing host E3 ligase CMPG1. Proc. Natl. Acad. Sci. USA 2010, 107, 9909-9914. [CrossRef]

81. Eschen-Lippold, L.; Landgraf, R.; Smolka, U.; Schulze, S.; Heilmann, M.; Heilmann, I.; Hause, G.; Rosahl, S. Activation of defence against Phytophthora infestans in potato by down-regulation of syntaxin gene expression. New Phytol. 2012, 193, 985-996. [CrossRef]

82. Niblett, C.L.; Bailey, A.M. Potential applications of gene silencing or RNA interference (RNAi) to control disease and insect pests of date palm. Emir. J. Food Agric. 2012, 24, 462-469.

83. Vetukuri, R.R.; Avrova, A.O.; Grenville-Briggs, L.J.; Van West, P.; Söderbom, F.; Savenkov, E.I.; Whisson, S.C.; Dixelius, C. Evidence for involvement of Dicer-like, Argonaute and histone deacetylase proteins in gene silencing in Phytophthora infestans. Mol. Plant Pathol. 2011, 12, 772-785. [CrossRef]

84. Qiao, L.; Lan, C.; Capriotti, L.; Ah-Fong, A.; Sanchez, J.N.; Hamby, R.; Heller, J.; Zhao, H.; Glass, N.L.; Judelson, H.S.; et al. Spray-induced gene silencing for disease control is dependent on the efficiency of pathogen RNA uptake. bioRxiv 2021. preprint. [CrossRef]

85. Gaulin, E.; Jauneau, A.; Villalba, F.; Rickauer, M.; Esquerre-Tugaye, M.T.; Bottin, A. The CBEL glycoprotein of Phytophthora parasitica varnicotianae is involved in cell wall deposition and adhesion to cellulosic substrates. J. Cell Sci. 2002, 115, 4565-4575. [CrossRef]

86. Hernández, I.; Chacón, O.; Rodriguez, R.; Portieles, R.; López, Y.; Pujol, M.; Borrás-Hidalgo, O. Black shank resistant tobacco by silencing of glutathione S-transferase. Biochem. Biophys. Res. Commun. 2009, 387, 300-304. [CrossRef] [PubMed]

87. Hua, C.; Wang, Y.; Zheng, X.; Dou, D.; Zhang, Z.; Govers, F.; Wang, Y. A Phytophthora sojae G-protein $\alpha$ subunit is involved in chemotaxis to soybean isoflavones. Eukaryot. Cell 2008, 7, 2133-2140. [CrossRef] [PubMed]

88. Wang, Y.; Dou, D.; Wang, X.; Li, A.; Sheng, Y.; Hua, C.; Cheng, B.; Chen, X.; Zheng, X.; Wang, Y. The PsCZF1 gene encoding a $\mathrm{C} 2 \mathrm{H} 2$ zinc finger protein is required for growth, development and pathogenesis in Phytophthora sojae. Microb. Pathog. 2009, 47, 78-86. [CrossRef]

89. Li, A.; Wang, Y.; Tao, K.; Dong, S.; Huang, Q.; Dai, T.; Zheng, X.; Wang, Y. PsSAK1, a stress-activated MAP kinase of Phytophthora sojae, is required for zoospore viability and infection of soybean. Mol. Plant Microbe Interact. 2010, 23, 1022-1031. [CrossRef] [PubMed]

90. Wang, Y.; Li, A.; Wang, X.; Zhang, X.; Zhao, W.; Dou, D.; Zheng, X.; Wang, Y. GPR11, a putative seven-transmembrane G protein-coupled receptor, controls zoospore development and virulence of Phytophthora sojae. Eukaryot. Cell 2009, 9, 242-250. [CrossRef] [PubMed]

91. Zhao, W.; Dong, S.; Ye, W.; Hua, C.; Meijer, H.J.; Dou, X.; Govers, F.; Wang, Y. Genome-wide identification of Phytophthora sojae SNARE genes and functional characterization of the conserved SNARE PsYKT6. Fungal Genet. Biol. 2011, 48, 241-251. [CrossRef]

92. Liu, T.; Ye, W.; Ru, Y.; Yang, X.; Gu, B.; Tao, K.; Lu, S.; Dong, S.; Zheng, X.; Shan, W.; et al. Two host cytoplasmic effectors are required for pathogenesis of Phytophthora sojae by suppression of host defenses. Plant Physiol. 2011, 155, 490-501. [CrossRef]

93. Erental, A.; Harel, A.; Yarden, O. Type 2A phosphoprotein phosphatase is required for asexual development and pathogenesis of Sclerotinia sclerotiorum. Mol. Plant Microbe Interact. 2007, 20, 944-954. [CrossRef] [PubMed]

94. Andrade, C.M.; Tinoco, M.L.P.; Rieth, A.F.; Maia, F.C.O.; Aragão, F.J.L. Host-induced gene silencing in the necrotrophic fungal pathogen Sclerotinia sclerotiorum. Plant Pathol. 2016, 65, 626-632. [CrossRef]

95. Laurie, J.D.; Linning, R.; Bakkeren, G. Hallmarks of RNA silencing are found in the smut fungus Ustilago hordei but not in its close relative Ustilago maydis. Curr. Genet. 2008, 53, 49-58. [CrossRef]

96. Song, Y.; Thomma, B.P.H.J. Host-induced gene silencing compromises Verticillium wilt in tomato and Arabidopsis. Mol. Plant Pathol. 2016, 19, 77-89. [CrossRef]

97. Zhang, T.; Jin, Y.; Zhao, J.H.; Gao, F.; Zhou, B.J.; Fang, Y.Y.; Guo, H.S. Host-induced gene silencing of the target gene in fungal cells confers effective resistance to the cotton wilt disease pathogen Verticillium dahliae. Mol. Plant 2016, 9, 939-942. [CrossRef]

98. Singh, S.; Braus-Stromeyer, S.A.; Timpner, C.; Tran, V.T.; Lohaus, G.; Reusche, M.; Knüfer, J.; Teichmann, T.; Tiedemann, A.V.; Braus, G.H. Silencing of Vlaro2 for chorismate synthase revealed that the phytopathogen Verticillium longisporum induces the cross-pathway control in the xylem. Appl. Microbiol. Biotechnol. 2010, 85, 1961-1976. [CrossRef]

99. Sohail, M.; Doran, G.; Riedemann, J.; Macaulay, V.; Southern, E.M. A simple and cost-effective method for producing small interfering RNAs with high efficacy. Nucleic Acids Res. 2003, 31, 38e. [CrossRef] [PubMed]

100. Nwokeoji, A.O.; Kumar, S.; Kilby, P.M.; Portwood, D.E.; Hobbs, J.K.; Dickman, M.J. Analysis of long dsRNA produced in vitro and in vivo using atomic force microscopy in conjunction with ion-pair reverse-phase HPLC. Analyst 2019, 144, 4985-4994. [CrossRef]

101. Yin, G.; Sun, Z.; Liu, N.; Zhang, L.; Song, Y.; Zhu, C.; Wen, F. Production of double-stranded RNA for interference with TMV infection utilizing a bacterial prokaryotic expression system. Appl. Microbiol. Biotechnol. 2009, 84, 323-333. [CrossRef]

102. Huang, L.; Jin, J.; Deighan, P.; Kiner, E.; McReynolds, L.; Lieberman, J. Efficient and specific gene knockdown by small interfering RNAs produced in bacteria. Nat. Biotechnol. 2013, 31, 350-356. [CrossRef] 
103. Ahn, S.-J.; Donahue, K.; Koh, Y.; Martin, R.R.; Choi, M.-Y. Microbial-based double-stranded RNA production to develop cost-effective RNA interference application for insect pest management. Int. J. Insect Sci. 2019, 11, 1-8. [CrossRef]

104. Beaucage, S.L.; Reese, C.B. Recent advances in the chemical synthesis of RNA. Curr. Protoc. Nucleic Acid Chem. 2009, 38, 2.16.1-2.16.31. [CrossRef]

105. Ahmadzada, T.; Reid, G.; McKenzie, D.R. Fundamentals of siRNA and miRNA therapeutics and a review of targeted nanoparticle delivery systems in breast cancer. Biophys. Rev. 2018, 10, 69-86. [CrossRef]

106. Song, X.-S.; Gu, K.-X.; Duan, X.-X.; Xiao, X.-M.; Hou, Y.-P.; Duan, Y.-B.; Wang, J.-X.; Zhou, M.-G. A myosin5 dsRNA that reduces the fungicide resistance and pathogenicity of Fusarium asiaticum. Pestic. Biochem. Physiol. 2018, 150, 1-9. [CrossRef]

107. Gaffar, F.Y.; Jafargholi, I.; Karlovsky, P.; Koch, A.M.; Kogel, K.H. Different components of the RNAi machinery are required for conidiation, ascosporogenesis, virulence, DON production and fungal inhibition by exogenous dsRNA in the head blight pathogen Fusarium graminearum. Front. Microbiol. 2019, 10, 1662. [CrossRef]

108. Höfle, L.; Biedenkopf, D.; Werner, B.T.; Shrestha, A.; Jelonek, L.; Koch, A. Study on the efficiency of dsRNAs with increasing length in RNA-based silencing of the Fusarium CYP51 genes. RNA Biol. 2020, 17, 463-473. [CrossRef]

109. Forster, H.; Shuai, B. Exogenous siRNAs against chitin synthase gene suppress the growth of the pathogenic fungus Macrophomina phaseolina. Mycologia 2020, 112, 699-710. [CrossRef] [PubMed]

110. Voloudakis, A.E.; Holeva, M.C.; Sarin, L.P.; Bamford, D.H.; Vargas, M.; Poranen, M.M.; Tenllado, F. Efficient double-stranded RNA production methods for utilization in plant virus control. Plant Virol. Protoc. 2015, 1236, 255-274.

111. Álvarez-Sánchez, A.R.; Romo-Quinones, C.; Rosas-Quijano, R.; Reyes, A.G.; Barraza, A.; Magallón-Barajas, F.; Angulo, C.; Mejía-Ruíz, C.H. Production of specific dsRNA against white spot syndrome virus in the yeast Yarrowia lipolytica. Aquac. Res. 2018, 49, 480-491. [CrossRef]

112. Taning, C.N.T.; Arpaia, S.; Christiaens, O.; Dietz-Pfeilstetter, A.; Jones, H.; Mezzetti, B.; Sabbadini, S.; Sorteberg, H.; Sweet, J.; Ventura, V.; et al. RNA-based biocontrol compounds: Current status and perspectives to reach the market. Pest. Manag. Sci. 2020, 76, 841-845. [CrossRef]

113. Tenllado, F.; Martínez-García, B.; Vargas, M.; Díaz-Ruíz, J.R. Crude extracts of bacterially expressed dsRNA can be used to protect plants against virus infections. BMC Biotechnol. 2003, 3, 3. [CrossRef]

114. Terpe, K. Overview of bacterial expression systems for heterologous protein production: From molecular and biochemical fundamentals to commercial systems. Appl. Microbiol. Biotechnol. 2006, 72, 211-222. [CrossRef]

115. Ongvarraspone, C.; Roshorm, Y.; Panyim, S. A simple and cost effective method to generate dsRNA for RNAi studies in invertebrates. ScienceAsia 2007, 33, 35-39. [CrossRef]

116. Thammasorn, T.; Sangsuriya, P.; Meemetta, W.; Senapin, S.; Jitrakorn, S.; Rattanarojpong, T.; Saksmerprome, V. Large-scale production and antiviral efficacy of multi-target double-stranded RNA for the prevention of white spot syndrome virus (WSSV) in shrimp. BMC Biotechnol. 2015, 15, 1-7. [CrossRef]

117. Zhu, J.; Dong, Y.-C.; Li, P.; Niu, C.-Y. The effect of silencing 20E biosynthesis relative genes by feeding bacterially expressed dsRNA on the larval development of Chilo suppressalis. Sci. Rep. 2016, 6, 28697. [CrossRef]

118. Newmark, P.A.; Reddien, P.W.; Cebrià, F.; Alvarado, A.S. Ingestion of bacterially expressed double-stranded RNA inhibits gene expression in planarians. Proc. Natl. Acad. Sci. USA 2003, 100, 11861-11865. [CrossRef]

119. Tian, H.; Peng, H.; Yao, Q.; Chen, H.; Xie, Q.; Tang, B.; Zhang, W. Developmental control of a lepidopteran pest Spodoptera exigua by ingestion of bacteria expressing dsRNA of a non-midgut gene. PLoS ONE 2009, 4, e6225. [CrossRef]

120. Sun, Y.; Qiao, X.; Mindich, L. Construction of carrier state viruses with partial genomes of the segmented dsRNA bacteriophages. Virology 2004, 319, 274-279. [CrossRef]

121. Aalto, A.P.; Sarin, L.P.; Van Dijk, A.A.; Saarma, M.; Poranen, M.M.; Arumae, U.; Bamford, D.H. Large-scale production of dsRNA and siRNA pools for RNA interference utilizing bacteriophage $\phi 6$ RNA-dependent RNA polymerase. RNA 2007, 13, 422-429. [CrossRef]

122. Niehl, A.; Soininen, M.; Poranen, M.M.; Heinlein, M. Synthetic biology approach for plant protection using dsRNA. Plant Biotechnol. J. 2018, 16, 1679-1687. [CrossRef]

123. Somchai, P.; Jitrakorn, S.; Thitamadee, S.; Meetam, M.; Saksmerprome, V. Use of microalgae Chlamydomonas reinhardtii for production of double-stranded RNA against shrimp virus. Aquac. Rep. 2016, 3, 178-183. [CrossRef]

124. Ghosh, S.K.B.; Hunter, W.B.; Park, A.L.; Gundersen-Rindal, D.E. Double-stranded RNA oral delivery methods to induce RNA interference in phloem and plant-sap-feeding hemipteran insects. J. Vis. Exp. 2018, 135, e57390. [CrossRef]

125. Dalakouras, A.; Wassenegger, M.; Dadami, E.; Ganopoulos, I.; Pappas, M.L.; Papadopoulou, K. Genetically modified organismfree RNA interference: Exogenous application of RNA molecules in plants. Plant Physiol. 2020, 182, 38-50. [CrossRef] [PubMed]

126. Dalakouras, A.; Wassenegger, M.; McMillan, N.; Cardoza, V.; Maegele, I.; Dadami, E.; Runne, M.; Krczal, G.; Wassenegger, M. Induction of silencing in plants by high-pressure spraying of in vitro synthesized small RNAs. Front. Plant Sci. 2016, 7, 1327. [CrossRef]

127. Wang, M.; Jin, H. Spray-induced gene silencing: A powerful innovative strategy for crop protection. Trends Microbiol. 2017, 25, 4-6. [CrossRef] [PubMed]

128. Sammons, R.; Ivashuta, S.; Liu, H.; Wang, D.; Feng, P.; Kouranov, A.; Andersen, S. Polynucleotide Molecules for Gene Regulation in Plants. U.S. Patent Application No. US20110296556A1, 1 December 2011. 
129. Mitter, N.; Worrall, E.A.; Robinson, K.E.; Xu, Z.P.; Carroll, B.J. Induction of virus resistance by exogenous application of double-stranded RNA. Curr. Opin. Virol. 2017, 26, 49-55. [CrossRef]

130. Vadlamudi, T.; Patil, B.L.; Kaldis, A.; Gopal, D.V.R.S.; Mishra, R.; Berbati, M.; Voloudakis, A. DsRNA-mediated protection against two isolates of Papaya ringspot virus through topical application of dsRNA in papaya. J. Virol. Methods 2020, 275, 113750. [CrossRef] [PubMed]

131. Whangbo, J.S.; Hunter, C.P. Environmental RNA interference. Trends Genet. 2008, 24, 297-305. [CrossRef]

132. Li, J.; Li, X.; Bai, R.; Shi, Y.; Tang, Q.; An, S.; Song, Q.; Yan, F. RNA interference of the P450 CYP6CM1 gene has different efficacy in B and Q biotypes of Bemisia tabaci. Pest Manag. Sci. 2015, 71, 1175-1181. [CrossRef]

133. Jeseničnik, T.; Štajner, N.; Radišek, S.; Jakše, J. RNA interference core components identified and characterised in Verticillium nonalfalfae, a vascular wilt pathogenic plant fungi of hops. Sci. Rep. 2019, 9, 8651. [CrossRef]

134. Wytinck, N.; Manchur, C.L.; Li, V.H.; Whyard, S.; Belmonte, M.F. dsRNA uptake in plant pests and pathogens: Insights into RNAi-based insect and fungal control technology. Plants 2020, 9, 1780. [CrossRef]

135. Numata, K.; Ohtani, M.; Yoshizumi, T.; Demura, T.; Kodama, Y. Local gene silencing in plants via synthetic dsRNA and carrier peptide. Plant Biotechnol. J. 2014, 12, 1027-1034. [CrossRef]

136. Dubrovina, A.S.; Aleynova, O.A.; Kalachev, A.V.; Suprun, A.R.; Ogneva, Z.V.; Kiselev, K.V. Induction of transgene suppression in plants via external application of synthetic dsRNA. Int. J. Mol. Sci. 2019, 20, 1585. [CrossRef] [PubMed]

137. Lichtenberg, S.S.; Tsyusko, O.V.; Palli, S.R.; Unrine, J.M. Uptake and bioactivity of chitosan/double-stranded RNA polyplex nanoparticles in Caenorhabditis elegans. Environ. Sci. Technol. 2019, 53, 3832-3840. [CrossRef]

138. Christiaens, O.; Whyard, S.; Vélez, A.M.; Smagghe, G. Double-stranded RNA technology to control insect pests: Current status and challenges. Front. Plant Sci. 2020, 11, 451. [CrossRef]

139. Zotti, M.J.; Smagghe, G. RNAi technology for insect management and protection of beneficial insects from diseases: Lessons, challenges and risk assessments. Neotrop. Entomol. 2015, 44, 197-213. [CrossRef] [PubMed]

140. Girard, I.J.; Tong, C.; Becker, M.G.; Mao, X.; Huang, J.; De Kievit, T.; Fernando, W.G.D.; Liu, S.; Belmonte, M.F. RNA sequencing of Brassica napus reveals cellular redox control of Sclerotinia infection. J. Exp. Bot. 2017, 68, 5079-5091. [CrossRef] [PubMed]

141. Young, S.W.S.; Stenzel, M.; Yang, J.L. Nanoparticle-siRNA: A potential cancer therapy? Crit. Rev. Oncol. Hematol. 2016, 98, 159-169. [CrossRef]

142. Lichtenberg, S.S.; Nuti, K.; DeRouchey, J.E.; Tsyusko, O.V.; Unrine, J.M. Efficacy of chitosan/double-stranded RNA polyplex nanoparticles for gene silencing under variable environmental conditions. Environ. Sci. Nano 2020, 7, 1582-1592. [CrossRef]

143. Kean, T.; Thanou, M. Biodegradation, biodistribution and toxicity of chitosan. Adv. Drug Deliv. Rev. 2010, 62, 3-11. [CrossRef]

144. Vázquez, J.A.; Rodríguez-Amado, I.; Montemayor, M.I.; Fraguas, J.; González, M.D.P.; Murado, M.A. Chondroitin sulfate, hyaluronic acid and chitin/chitosan production using marine waste sources: Characteristics, applications and eco-friendly processes: A review. Mar. Drugs 2013, 11, 747-774. [CrossRef]

145. Zhang, X.; Zhang, J.; Zhu, K.Y. Chitosan/double-stranded RNA nanoparticle-mediated RNA interference to silence chitin synthase genes through larval feeding in the African malaria mosquito (Anopheles gambiae). Insect Mol. Biol. 2010, 19, 683-693. [CrossRef]

146. Wang, K.; Peng, Y.; Chen, J.J.; Peng, Y.; Wang, X.; Shen, Z.; Han, Z. Comparison of efficacy of RNAi mediated by various nanoparticles in the rice striped stem borer (Chilo suppressalis). Pestic. Biochem. Physiol. 2020, 165, 104467. [CrossRef]

147. Schwartz, S.H.; Hendrix, B.; Hoffer, P.; Sanders, R.A.; Zheng, W. Carbon dots for efficient siRNA delivery and gene silencing in plants. Plant Physiol. 2020, 184, 647-657. [CrossRef]

148. Lin, Y.-H.; Huang, J.-H.; Liu, Y.; Belles, X.; Lee, H.-J. Oral delivery of dsRNA lipoplexes to German cockroach protects dsRNA from degradation and induces RNAi response. Pest Manag. Sci. 2016, 73, 960-966. [CrossRef]

149. Nami, S.; Baradaran, B.; Mansoori, B.; Kordbacheh, P.; Rezaie, S.; Falahati, M.; Khosroshahi, L.M.; Safara, M.; Zaini, F. The utilization of RNA silencing technology to mitigate the voriconazole resistance of Aspergillus flavus; Lipofectamine-based delivery. Adv. Pharm. Bull. 2017, 7, 53-59. [CrossRef]

150. Adams, S.; Pathak, P.; Shao, H.; Lok, J.B.; Pires-Dasilva, A. Liposome-based transfection enhances RNAi and CRISPR-mediated mutagenesis in non-model nematode systems. Sci. Rep. 2019, 9, 483. [CrossRef]

151. Kim, D.H.; Rossi, J.J. Strategies for silencing human disease using RNA interference. Nat. Rev. Genet. 2007, 8, 173-184. [CrossRef] [PubMed]

152. Rettig, G.R.; Behlke, M.A. Progress toward in vivo use of siRNAs-II. Mol. Ther. 2013, 20, 483-512. [CrossRef]

153. Jiang, L.; Ding, L.; He, B.; Shen, J.; Xu, Z.; Yin, M.; Zhang, X. Systemic gene silencing in plants triggered by fluorescent nanoparticle-delivered double-stranded RNA. Nanoscale 2014, 6, 9965-9969. [CrossRef] [PubMed]

154. Dalakouras, A.; Jarausch, W.; Buchholz, G.; Bassler, A.; Braun, M.; Manthey, T.; Krczal, G.; Wassenegger, M. Delivery of hairpin RNAs and small RNAs into woody and herbaceous plants by trunk injection and petiole absorption. Front. Plant Sci. 2018, 9 , 1253. [CrossRef]

155. Tenllado, F.; Díaz-Ruíz, J.R. Double-stranded RNA-mediated interference with plant virus infection. J. Virol. 2001, 75, 12288-12297. [CrossRef] [PubMed]

156. Weiberg, A.; Wang, M.; Lin, F.M.; Zhao, H.; Zhang, Z.; Kaloshian, I.; Huang, H.D.; Jin, H. Fungal small RNAs suppress plant immunity by hijacking host RNA interference pathways. Science 2013, 342, 118-123. [CrossRef] [PubMed] 
157. Melnyk, C.W.; Molnar, A.; Baulcombe, D.C. Intercellular and systemic movement of RNA silencing signals. EMBO J. 2011, 30, 3553-3563. [CrossRef]

158. Hunter, W.B.; Glick, E.; Paldi, N.; Bextine, B.R. Advances RNA interference: dsRNA treatment in trees and grapevines for insect pest population suppression. Southwest. Entomol. 2012, 37, 85-87. [CrossRef]

159. De Andrade, E.C.; Hunter, W.B. Ribonucleic acid interference (RNAi): A natural gene based technology for highly specific pest control (HiSPeC). In RNA Interference; Abdurakhmonov, I.Y., Ed.; IntechOpen: Rijeka, Croatia, 2016; pp. 391-409. [CrossRef]

160. Power, I.L.; Faustinelli, P.C.; Orner, V.A.; Sobolev, V.S.; Arias, R.S. Analysis of small RNA populations generated in peanut leaves after exogenous application of dsRNA and dsDNA targeting aflatoxin synthesis genes. Sci. Rep. 2020, 10, 13820. [CrossRef]

161. Hamilton, A.J.; Baulcombe, D.C. A species of small antisense RNA in posttranscriptional gene silencing in plants. Science 1999, 286, 950-952. [CrossRef]

162. Chen, H.-M.; Chen, L.-T.; Patel, K.; Li, Y.-H.; Baulcombe, D.C.; Wu, S.-H. 22-nucleotide RNAs trigger secondary siRNA biogenesis in plants. Proc. Natl. Acad. Sci. USA 2010, 107, 15269-15274. [CrossRef]

163. Wu, H.; Li, B.; Iwakawa, H.-O.; Pan, Y.; Tang, X.; Ling-Hu, Q.; Liu, Y.; Sheng, S.; Feng, L.; Zhang, H.; et al. Plant 22-nt siRNAs mediate translational repression and stress adaptation. Nature 2020, 581, 89-93. [CrossRef]

164. Chan, S.W.-L.; Zilberman, D.; Xie, Z.; Johansen, L.K.; Carrington, J.C.; Jacobsen, S.E. RNA Silencing genes control de Novo DNA methylation. Science 2004, 303, 1336. [CrossRef]

165. Wassenegger, M.; Heimes, S.; Riedel, L.; Sänger, H.L. RNA-directed de novo methylation of genomic sequences in plants. Cell 1994, 76, 567-576. [CrossRef]

166. Taning, C.N.T.; Mezzetti, B.; Kleter, G.; Smagghe, G.; Baraldi, E. Does RNAi-based technology fit within EU sustainability goals? In Trends Biotechnol.; 2020; in press. [CrossRef]

167. Arpaia, S.; Christiaens, O.; Giddings, K.; Jones, H.; Mezzetti, B.; Moronta-Barrios, F.; Perry, J.N.; Sweet, J.B.; Taning, C.N.T.; Smagghe, G.; et al. Biosafety of GM crop plants expressing dsRNA: Data requirements and EU regulatory considerations. Front. Plant Sci. 2020, 11, 940. [CrossRef]

168. Dillin, A. The specifics of small interfering RNA specificity. Proc. Natl. Acad. Sci. USA 2003, 100, 6289-6291. [CrossRef] [PubMed]

169. Lundgren, J.G.; Duan, J.J. RNAi-based insecticidal crops: Potential effects on nontarget species. BioScience 2013, 63, 657-665. [CrossRef]

170. Jackson, A.L.; Bartz, S.R.; Schelter, J.; Kobayashi, S.V.; Burchard, J.; Mao, M.; Li, B.; Cavet, G.; Linsley, P.S. Expression profiling reveals off-target gene regulation by RNAi. Nat. Biotechnol. 2003, 21, 635-637. [CrossRef] [PubMed]

171. Davidson, B.L.; Mccray, P.B. Current prospects for RNA interference-based therapies. Nat. Rev. Genet. 2011, 12, 329-340. [CrossRef]

172. Altschul, S.F.; Gish, W.; Miller, W.; Myers, E.W.; Lipman, D.J. Basic local alignment search tool. J. Mol. Biol. 1990, 215 , 403-410. [CrossRef]

173. Elbashir, S.M.; Harborth, J.; Weber, K.; Tuschl, T. Analysis of gene function in somatic mammalian cells using small interfering RNAs. Methods 2002, 26, 199-213. [CrossRef] 